\title{
GANANCIA GENÉTICA, CULTIVO IN VITRO Y ADAPTACIÓN DE PAPA A LAS ZONAS AGROECOLÓGICAS ÁRIDAS Y SALINAS DE LA COSTA PERUANA
}

\author{
René Chavez', Arie Wijntje ${ }^{3}$, Rafael Berríos ${ }^{1}$ \\ Mahesh Upadhya ${ }^{2}$, Percy Zúñiga ${ }^{3}$, Soledad Colque \\ ', Rolando Cabello ${ }^{2}$, Jorge Espinoza ${ }^{2}$, Gladys \\ Cueva ${ }^{1}$, Humberto Mendoza ${ }^{2}$, Walter Amoros ${ }^{2}$, \\ Giorgio Bollo ', Porfirio Siles ', Katya Monasterio', \\ Marco Huacollo '
}

\section{RES U MEN}

En enero de 1985, se establece el proyecto de investigación colaborativa Mejoramiento Genético de Papa y Camote para Zonas Áridas y Salinas entre la Facultad de Ciencias Agrícolas de la Universidad Nacional Jorge Basadre Grohmann de Tacna y el Centro Internacional de la Papa. Dentro de la estrategia y logística del presente proyecto se diseñó un programa de cruzamientos y selecciones recurrentes para generar híbridos y clones avanzados, así como progenitores con buena habilidad combinatoria, adaptados a las condiciones agroecológicas áridas y salinas de la costa peruana. Este germoplasma autotetraploide mejorado $(2 n=4 x=48=A A A A)$, introducido al sistema de cultivo in vitro para su limpieza de virus y liberación, sería utilizado por los agricultores de esta zona agroecológica para la alimentación humana y como materia prima para la agroindustria.

A la fecha, se ha logrado una amplia ganancia genética y un avance de selección, materializado mayormente por un caudal de clones avanzados, familias híbridas de semilla botánica y variedades superiores, adaptadas a las condiciones climáticas y edáficas de los suelos costeros de potencial agrícola, así como una amplia resistencia de campo al nemátodo del nudo de la raíz Meloidogyne incógnita M.javanica y M. arenaria, importante plaga de la papa y una resistencia de campo a los principales virus del tubérculo, como parte de un manejo ecológico integrado, en el control de plagas y enfermedades en la costa árida peruana.

\section{A B STRACT}

In january 1985 was established a collaborative research project on "Breeding potatoes and Sweet potatoes for Adaptation to arid and saline soil conditions" between the Faculty of Agronomy of the National University of Tacna and The International Potato Center. Within the breeding strategy and logistic of the project it was designed a crossing program based on cycles of recurrent selection in order to generate advanced hybrids and clones, as well as parentals with good combining ability showing adaptation to the arid and saline soil conditions from the arid agroecological region of the Peruviam coast. This improved autotetraploid germplasm $(2 n=4 x=48=A A A A)$, once introduced to the in vitro culture system for virus elimination, and released would be utilized by farmers for food and processing. After 12 years of intensive and continuous field experiments it was generated a great amount of useful information and an extent advance of selection and genetic gain in the improved potato germplasm, which mainly comprises a broaden gene pool of advanced clones, TPS hybrid families, and released superior varieties adapted to the most common abiotic stresses of arid lands, as well as a high

I Facultad de Ciencias Agrícolas, Universidad Nacional Jorge Basadre Grohmann de Tacna.

2 Departamentos de Fisiología y Genética; Centro Internacional de la Papa. Lima-Perú.

3 Convenio ALA/93; Comunidad Económica Europea-Irrigación Majes. Arequipa-Perú. 


\section{INTRODUCCIÓN}

Dentro de la clasificación general de las zonas agroecológicas del mundo, la zona árida es el ambiente ecológico más extenso en el cinturón tropical del Tercer Mundo y es la que presenta los mayores estreses abióticos a las plantas cultivadas, principalmente sequia, salinidad, toxicidad de boro y calor. Estos estreses no sólo reducen los rendimientos de las plantas cultivadas, sino también limitan la extensión y explotación racional de nuevas variedades comerciales susceptibles a éstos. El manejo integrado de los estreses [PR1][PR2] abióticos en las zonas áridas de potencial agrícola, siempre ha sido fuertemente orientado al manejo altamente tecnificado del agua y suelo, así como la selección del cultivo en la estación óptima del año (Espinoza et al,1986). Sin embargo, recién desde la última década se ha venido dando mayor importancia a otro componente del manejo integrado de zonas áridas, el potencial genético de las especies cultivadas para tolerar los estreses abióticos, como producto de una superioridad heredada o una combinación favorable de genes bajo la mano del fitomejorador moderno (Chávez et al,1996).

El potencial agricola de la zona agroecológica árida y salina de Sudamérica es inmenso, abarca prácticamente todo el territorio costanero del Perú y norte de Chile, con una extensión aproximada de 4000 kilómetros de largo y un promedio de 80 kilómetros de ancho. Dentro de esta zona se encuentran los grandes desiertos de Sechura y Atacama. La naturaleza, como producto de la evolución darwiniana durante miles o millones de años, ha generado especies vegetales con alta frecuencia de genes de resistencia a la sequia, salinidad y toxicidad de boro, tal es el caso del tamarugo Prosopis tamarugo del desierto de Atacama y del tomate Lycopersicon peruvianum y $L$. chilensi del desierto peruano. En este sentido, el avance de los cultivos hacia zonas marginales mayormente áridas y salinas, ha hecho que se preste una especial atención a la investigación sobre respuestas fenotípicas de las plantas a la salinidad y al estrés de la sequia. Para el caso particular de la papa, los estreses abióticos, edáficos y las altas temperaturas de primavera y verano, limitan la producción sostenida del cultivo, asi como el suministro permanente de materia prima fresca para la agroindustria.

Doce años de intensiva y continua experimentación genética en papa, tanto en campos experimentales como en chacras de agricultores, generaron más de 32,000 clones y familias híbridas promisorias. De este material se seleccionaron 105 clones avanzados y 37 clones superiores muy precoces, adaptados a las condiciones áridas y salinas, y de alta calidad para la agroindustria. Ocho clones superiores introducidos al sistema de cultivo in vitro para la eliminación de virus.
De este grupo, cinco clones fueron micropropagados, multiplicados, nominados y liberados para la zona agrícola costera. De todo el germoplasma mejorado, solamente siete clones superiores han mostrado también adaptación a las zonas semiáridas altoandinas (3000 msnm). Por otra parte, doce familias hibridas ya podrían ser usadas en la producción comercial de papa, a partir de semilla botánica en zonas áridas con niveles bajos de salinidad y boro. Actualmente, el germoplasma mejorado también incluye un grupo de 14 clones promisorios de papa con buena habilidad combinatoria para ser usados en el futuro en la generación de familias hibridas de semilla botánica y para la selección de clones superiores adaptados a la zona agroecológica árida del cinturón tropical.

\section{LA ZONA AGROECOLÓGICA ÁRIDA Y SALINA DE LA COSTA PERUANA: CARACTERISTÍCAS CLIMÁTICAS Y EDÁFICAS}

La zona agroecológica árida y salina con potencial agricola de la costa peruana comprende un territorio con cerca de cinco millones de hectáreas. Sin embargo, sólo una pequeña fracción de este territorio es cultivado debido a los estreses abióticos, mayormente edáficos, que afectan el rendimiento y la productividad de las plantas cultivadas. En general, los estreses abióticos climáticos no son tan severos como en otras zonas agroecológicas del Perú. Sin embargo, la baja temperatura durante el invierno, especialmente en la costa surperuana, limita la explotación sostenida de cultivos comerciales como es el caso del tomate. La alta temperatura reinante durante la primavera y el verano también es un factor fuertemente limitante para algunos cultivos comerciales, como el caso de la papa, cuya tuberización es inhibida por el calor. Otro singular estrés abiótico-climático que podríamos considerar son las diferencias de fotoperiodo durante el año, sobre todo en el sur del Perú y bajo latitud $17^{\circ}$ y $18^{\circ}$ Sur. La mayoría de las especies cultivadas tienen un fotoperiodo óptimo para su máximo rendimiento y son sensibles cuando se les cultiva bajo diferentes fotoperiodos, sea largo (días largos de verano) o corto (días cortos de invierno). En el extremo sur del Perú (Tacna y Moquegua) hay una respuesta fenotípica efectiva de las plantas cultivadas a los diferentes fotoperiodos que marcadamente se aprecian durante las cuatro estaciones del año. Para una producción sostenida durante todo el año de un cultivo anual y precoz sería necesario disponer variedades insensibles al fotoperiodo. Aunque parezca una simple teoría genética, existe en realidad variabilidad genética para adaptación de las plantas a diferentes fotoperiodos o insensibilidad a este estrés. Lógicamente, la variabilidad buscada se encuentra su naturaleza genética es compleja y su gobierno es poligénico. 
Los estreses abióticos edáficos son más determinantes en la producción sostenida de los cultivos. Uno de los mayores estreses es la salinidad de estas zonas áridas. La sal dominante es el cloruro de sodio de origen marino, encontrándose en el suelo a niveles elevados que fluctúan entre 5 y $20 \mathrm{mmhs} /$ $\mathrm{cm}$.y en una capa arable de $20 \mathrm{~cm}$. de profundidad. El otro estrés importante es la ocurrencia de boro en el suelo, pero a niveles mayormente tóxicos, cuya fluctuación común va de 4 a 10 ppm en una capa arable de 20 a $25 \mathrm{~cm}$. Los estudios edafológicos in situ y los análisis en laboratorio muestran la existencia de una gran variabilidad dinámica horizontal, vertical y temporal de la salinidad en los diferentes estratos y horizontes edáficos. La variabilidad dinámica temporal es notoria cuando estos suelos salinos son irrigados. En este sentido, en enero de 1985 se inicia la ejecución del presente proyecto con el muestreo y análisis sistemático de los suelos áridos. Hasta ahora, los análisis se siguen realizando aunque en menor escala. A la fecha se han analizado más de 2200 muestras de suelos áridos y salinos. Los análisis se han hecho en los laboratorios de química de la Universidad Nacional de Tacna, Universidad Agraria La Molina y del Instituto de Agronomía de la Universidad de Tarapacá. Las muestras de suelos se han colectado mayormente en tres zonas: a) suelos desérticos vírgenes b) suelos cultivados irrigados y c) suelos cultivados abandonados ( $\sin$ riego ). Asimismo, se realizaron numerosas calicatas para muestrear suelos en los diferentes horizontes, desde la superficie hasta 1,2 m. de profundidad. Los resultados de los análisis de los suelos desérticos virgenes, han sido sorprendentes, detectándose una enorme variabilidad horizontal y vertical de la concentración de sales en los estratos edáficos. Las franjas horizontales de salinidad pueden variar de 10 a 120 mmhs en pocos metros o kilómetros. La variabilidad vertical de los horizontes edáficos, es aún más conspicua, variando en algunos casos de 8 a $50 \mathrm{mmhs}$, a pocos centímetros o decímetros.

El contenido de boro en el suelo puede variar vertical u horizontalmente de 4 a $10 \mathrm{ppm}$. y excepcionalmente de 4 a 14 ppm., como ocurre en los valles de Sama, Locumba e Ite. La dinámica del contenido de sales solubles en los suelos cultivados irrigados, involucra además de la variabilidad horizontal y vertical, la variabilidad temporal o estacional. En general, los niveles de salinidad bajan gradualmente a medida que se incrementa el número de riegos, siendo éstos cada siete u ocho días (mita). En muchos suelos áridos y franco-arenosos, el contenido de sales baja a su nivel inferior el día de riego y se va incrementando a partir del segundo día hasta el séptimo u octavo día que nuevamente es irrigado. Este cambio se hace más dinámico durante el verano que en el invierno, y más aún en los suelos arenosos y franco-arenosos con poca capacidad de campo por el exceso de evaporación de agua del suelo, que arrastra las sales de los horizontes bajos hacia la superficie. Sin embargo, toda esta variabilidad de la salinidad en el tiempo, se lleva a cabo mayormente en el fondo del surco y en los niveles freáticos de riego. El lomo del surco (nivel no freático) permanece relativamente estable con niveles elevados de sal debido a la constante migración vertical de las sales de la parte húmeda a la parte seca. Se ha detectado en algunos suelos fuertemente salinos, que la conductividad puede variar entre el fondo y el lomo del surco de 5 a $50 \mathrm{mmh}$, tal es el caso de algunos suelos de La Yarada y Los Palos, ubicados todavía dentro del desierto de Atacama en el departamento de Tacna.

Observaciones realizadas en suelos cultivados, abandonados ya sin riego, indican que la salinidad aumenta considerablemente desde la última irrigación que se hizo al cultivo. La sal es arrastrada a estratos superiores a medida que el suelo va perdiendo toda el agua disponible, generalmente se presentan cristalizaciones blancas de sal en la superficie de los suelos abandonados. Consecuentemente, los niveles de sal son superiores a los de antes del cultivo, tanto en el fondo del surco como (mayor) en el lomo del surco El agua de origen subterráneo extraida de los pozos que se utiliza en la irrigación de cultivos es ligeramente salina, con una concentración que fluctúa de 1 a $3 \mathrm{mmh} /$ $\mathrm{cm}$, variando de acuerdo a su proximidad al mar. Al evaporarse el agua de riego, contribuye aunque en poca escala, a la salinización del suelo debido a la ausencia de drenajes. Por otra parte, el agua de riego de origen altoandino, proveniente mayormente de las lagunas en el sur del Perú, contiene niveles moderados de boro que al evaporarse contribuye también al incremento del boro tóxico en el suelo cultivado, causando daños fisiológicos a las plantas cultivadas. Hipersensibilidad a niveles moderados de toxicidad de boro, pueden observarse en las hojas cloróticas de los cítricos y en la fuerte quemadura del borde de las hojas de plantas de palto, guayaba y lúcuma. Sin embargo, en algunas regiones de la costa peruana, la presencia en el suelo de carbonato de calcio reduce los efectos perniciosos del boro a niveles tóxicos.

En algunos cultivos anuales y hortalizas, los aporques realizados durante el cultivo también producen un gran estrés en las plantas. Cada aporque arrastra gran cantidad de sales de la parte superior no freática de los surcos hacia la base de los tallos de la planta. Una vez irrigado, las sales disueltas van hacia la zona radicular de la planta, produciendo quemaduras y clorosis en hojas y acelerando la senescencia de las plantas, como el caso del tomate, maiz y papa. El riego tecnificado presurizado ya sea por goteo, aspersión, burbujeo o 
exudación, tiene la ventaja de mantener el suelo con niveles bajos de salinidad en la zona radicular y freática (húmeda). Se observa una migración de sales horizontalmente a pocos decímetros de la planta, durante todo el ciclo vegetativo del cultivo. Además, en el riego tecnificado no se requiere de aporques, o en el caso particular de la papa, muy poco, evitando de esta manera grandes acumulaciones temporales de sales en la base de la planta. Sin embargo, una vez retiradas las mangueras de riego o cintas exudantes, las sales migrarán nuevamente a la superficie del suelo. Un riego tecnificado mal conducido puede producir mucho estrés en la planta, debido a que la napa freática de este sistema es relativamente poca. Esto ocurre sobre todo en el riego por goteo y por medio de cintas exudantes utilizadas en las zonas desérticas. Se ha detectado que la salinidad decrece comúnmente a medida que se aleja del mar, hasta llegar a niveles muy bajos no estresantes, lo cual ocurre frecuentemente en suelos ubicados a altitudes de 900-1000 m.s.n.m. Asimismo, la textura es francoarenosa a nivel del mar y va aumentando gradualmente en el contenido de arcilla. Esto involucra, consecuentemente, el incremento de la capacidad de campo del suelo o la retención de agua en el suelo, disminuyendo de esta manera el estrés hídrico en los cultivos.

Los experimentos de campo conducidos desde el nivel del mar hasta 900-1000 msnm, nos indican que partiendo de altitudes entre 800-1000 msnm hasta el nivel del mar, la población de nemátodos, sobre todo del nemátodo del nudo de la raíz (RKN) Meloydogine incógnita, M.javanica y M.arenaria, aumenta vertiginosamente, encontrándose alta presión poblacional en los suelos francoarenosos cerca del mar. Esto nos muestra la correlación existente entre la textura franco arenosa del suelo y el grado de presión poblacional del nemátodo del nudo de la raiz, plaga muy importante de muchos cultivos de la costa del Pacífico Sur, el cual limita el cultivo comercial de especies y variedades susceptibles a esta plaga.

Los suelos de la zona agroecológica árida y salina del Perú, sobre todo del sur con potencial agricola, tiene niveles muy bajos de materia orgánica y en general son deficientes en fósforo y nitrógeno. Es extremadamente importante la incorporación de grandes cantidades de abono orgánico para mantener el equilibrio biológico del suelo, suministrando nutrientes a la planta y retener más agua en el suelo, además de reducir el daño causado por nemátodos, debido al incremento en la microflora benéfica. Dentro de la estrategia y logistica de un programa de cultivos en las zonas áridas y salinas, se debe considerar un manejo integrado para el control de los estreses abióticos, orientados a un rendimiento comercial, lógicamente esto comprende tres aspectos fundamentales: el manejo del suelo, del riego y la variedad mejorada tolerante o resistente a los estreses abióticos más comunes.

\section{III.ADAPTACIÓN DE FAMILIAS HÍBRIDAS DE SEMILLA BOTÁNICA A ZONAS ÁRIDAS}

Como parte de la estrategia de selección, se inicia dentro del proyecto colaborativo, los experimentos conducentes a la adaptación de líneas o hibridos de semilla botánica de papa a las zonas áridas y salinas del sur del Perú desde inicios de 1986. En esta primera etapa se evaluaron 63 familias hibridas con un total de 17000 genotipos o seedlings. Los estreses de calor y salinidad dañaron a las plantas trasplantadas en estos suelos regados por gravedad o inundación parcial. No se seleccionó ninguna familia promisoria, sólo unos cuantos genotipos que sobrevivieron y lograron tuberizar en las condiciones de estrés del desierto. Estos clones promisorios iniciales fueron multiplicados y sometidos a las pruebas serológicas de resistencia a virus y multiplicadas en invernadero para evaluaciones en experimentos de campo (Chávez et al, 1996).

\subsection{EVALUACIÓN DE HÍBRIDOS PROMISORIOS}

A principios de 1991 se ensaya otra estrategia de evaluación de familias de semilla botánica (TPS), con progenies cuyos clones parentales habian sido previamente seleccionados en zonas áridas por su tolerancia a estreses abióticos (Upadhya y Thakur,1990). El experimento fue conducido en suelos áridos moderadamente salinos, utilizando riego por exudación. De diez familias evaluadas, se logró seleccionar la familia promisoria C89.437 x ST.BULK, la cual mostró mayor frecuencia de genotipos adaptados con caracteres agronómicos deseables, seguida de la familia TPS387776.3 x ST.BULK. En ambas familias, el progenitor masculino fue una mezcla de polen de varios clones tolerantes a estreses abióticos (ST) (Chávez, 1995).

En un intento de identificar familias de TPS con buena performancia agronómica se experimenta a principios de 1994 un nuevo set de hibridos superiores TPS en zonas áridas, con suelos ligeramente salinos en diseños de blocks completamente randomizados con cuatro repeticiones y a una altitud de $900 \mathrm{msnm}$. Cada familia TPS fue experimentada asociadamente con su correspondiente familia-tubérculo (ST) dentro del diseño experimental. Las familias TPS que más sobrevivieron a los estreses abióticos fueron serrana $\times$ LT.9 y LT.9 $\times$ TS.9 La variabilidad intra-familias permitió seleccionar 24 clones promisorios con potencial genético para una producción comercial. Sin embargo, las familias tubérculos, de primera generación clonal de tuberculillos, mostraron mayor adaptación a los estreses, siendo los híbridos chiquita en baja frecuencia, 
$x$ TS.4 y serrana $x$ LT.7, los mejores rendidores en tubérculos, lográndose seleccionar 30 genotipos promisorios. En términos de rendimiento, ninguna de las familias de tubérculos o TPS superó en rendimiento a la variedad costanera usada como control. Las mismas diez familias TPS evaluadas para rendimiento de tuberculillos en sustratos artificiales de invernadero, mostraron variabilidad enorme en el rendimiento, siendo los híbridos serrana $x$ LT.7 y LT.9 x 104.12.LB, los de mayor rendimiento de tuberculillos por $\mathrm{m}^{2}$, con 350 a 450 tuberculillos $/ \mathrm{m}^{2}$ respectivamente. La familia TPS. serrana $\times$ LT.7 parece ser la más adaptable a condiciones áridas, sin embargo, es necesario descartar experimentalmente alguna correlación positiva existente entre el efecto de estrés abiótico y la mayor producción de glicoalcaloides (solanina) en los tubérculos de papa provenientes de TPS o de ST. Esta detección se puede hacer con simples pruebas sistemáticas del sabor amargo de la papa sancochada.

Bajo condiciones de alta temperatura y fotoperiodo largo, en el verano de 1995, se evaluaron diez familias de tuberculillos (ST) provenientes de semilla botánica (TPS) cultivadas en sustratos de $1 \mathrm{~m} 2$. Los tuberculillos fueron sembrados en suelos áridos y ligeramente salinos, a $900 \mathrm{msnm}$. Las plantas mostraron un alto vigor (7 a 9) en el follaje, similar al vigor observado en los controles usando tubérculos normales de las variedades tacna y costanera. Asimismo, todas las familias mostraron follaje normal, ausente de sintomas de enfermedades viróticas. La sobrevivencia de las plantas fue del $90 \%$ en contraposición de las plántulas de semilla botánica anteriormente evaluadas (cerca del $40 \%$ de sobrevivencia). La mayor performancia agronómica en la produccción de tubérculos fue observada en la familia serrana x LT.7, con una alta uniformidad en color, forma y tamaño y con un rendimiento de $564 \mathrm{gr} / \mathrm{planta}$. En segundo lugar, se registra el hibrido LT. $9 \times 104.12$ LB con un rendimiento de $528 \mathrm{gr} /$ planta, pero la calidad comercial de los tubérculos fue inferior. Ambos híbridos provienen de parentales tolerantes al calor y con genes de resistencia de campo a los virus PVX, PVY y PLRV.

Los resultados de estos experimentos preliminares de campo con TPS y ST, mostraron una posible alternativa del uso de la semilla botánica (TPS) y tuberculillos de primera generación clonal (ST.1) en la producción comercial de papa en zonas áridas con estreses abióticos edáficos moderados (Chávez et al, 1996).

\subsection{PERFORMANCIA AGRONÓMICA DE FAMILIAS TPS. EN SUELOS ÁRIDOS MUY SALINOS}

Con la finalidad de determinar la performancia agronómica e identificar clones o genotipos promisorios dentro de cada familia, se tamizó 15 familias TPS bajo condiciones de suelos áridos muy salinos y con niveles medios de boro tóxico durante el invierno de 1995. En esta oportunidad, los progenitores de las familias TPS fueron seleccionados en Tacna por su tolerancia a salinidad, sequia, calor, precocidad y resistencia a RKN. Se utilizó como control, la semilla de polinización libre de la variedad tikahuasi susceptible a salinidad. El experimento se llevó a cabo en la localidad de Magollo, $400 \mathrm{msnm}$, bajo riego por inundación y en suelos agrícolas fuertemente salinos. Los resultados nos darian también alguna información sobre la habilidad combinatoria para salinidad y sequía de los clones élites parentales. Se utilizaron 80 genotipos o plántulas por familia, distribuidos en blocks completamente randomizados y con cuatro repeticiones, es decir, 20 plantas por repetición. La conductividad eléctrica del terreno experimental fluctuó entre 10-18 mms y el contenido de boro 3-9 ppm antes del riego.

Mayor sobrevivencia al transplante, después de 15 dias, fue observada en las familias TPS, SDC89.315 x ST.BULK con $72 \%$, SDC89.302 $\times$ SDC89.315 con $71 \%$ y SDC 90.259 x ST.BULK con $65 \%$ de sobrevivencia. El control de la vr. tikahuasi (TPS) mostró muy baja sobrevivencia (14\%). La segunda evaluación de sobrevivencia realizada a 60 dias, después del transplante, muestra solamente mayor frecuencia de plantas sobrevivientes con un vigor promedio de 3 , (no se registró mayor vigor) en las siguientes familias promisorias: SDC91.934 x SDC89.315 con 36\%; C90.259 x ST.BULK con $30 \%$ y SDC89.308 x ST.BULK con $27 \%$ de sobrevivencia. Sin embargo, no hubo una fuerte corrrelación en algunas familias en la frecuencia de supervivencia y la capacidad de tuberización y produccion de tuberculillos de buena calidad. Se logró identificar a las familias con mayor frecuencia de producción de tuberculillos de calidad: SDC90.259 x ST.BULK, SDC91.934 x SDC89.315, SDC89.315 x ST.BULK y SDC91.902 x SDC89.315. El tamizado de estas 15 familias nos indica que los clones élites utlizados como parentales SDC89.315, SDC90.259 Y SDC90.260, tienen buena habilidad combinatoria para resistencia a suelos muy salinos, debido a que proporcionan en la primera generación mayor frecuencia de híbridos o genotipos resistentes a salinidad. Por consiguiente, las mejores combinaciones para suelos muy salinos serian: SDC90.259 x ST:BULK, SDC91.934 x SDC89.315 y SDC89.315 x ST:BULK. Sin embargo, tendría que evaluarse estas mismas familias ya preseleccionadas bajo condiciones de verano o de dias largos. Un total de cerca de 150 genotipos o plántulas fueron seleccionadas para su multiplicación, ensayos avanzados, pruebas de ELISA y otras pruebas de calidad. Estas fueron realizadas en La Molina-Lima, bajo condiciones de invernadero y 
suelos no estresados en el campo.

\subsection{EVALUACIÓN DE FAMILIAS HÍBRIDAS SUPERIORES DE TPS BAJO CONDICIONES DE ESTRÉS MODERADO}

\subsubsection{Experimento TPS.1}

Una nueva estrategia en la producción comercial de papa a partir de semilla botánica (TPS) es aplicada a mediados de 1995 en zonas áridas con estreses abióticos edáficos moderados. Se seleccionaron previamente un grupo de diez híbridos superiores, cuyos progenitores, probablemente tenían una buena habilidad combinatoria para atributos agronómicos y cuyas semillas híbridas fueron seleccionadas por su alta calidad de embriones (vigorosos y bien formados). El potencial genético de estos híbridos fue puesto a prueba en suelos áridos y ligeramente salinos, bajo condiciones de baja temperatura y fotoperiodo corto, en Pachia y Tacna (950 $\mathrm{msnm}$ ). El material fue trasplantado de almácigo al campo y el follaje fue cortado a los 80 dias a fin de determinar también su precocidad. Se evaluó la sobrevivencia y el vigor del follaje a los 60 días del trasplante, habiéndose detectado lo siguiente:

a) Se observó una alta frecuencia de sobrevivencia de las plantas trasplantadas.

b) Se detectó un incremento conspicuo en el vigor de las plantas en las familias. En algunas familias y repeticiones se observó un grado de vigor 9 .

c) Se observó una mayor frecuencia de genotipos ideales para ser usados, ya sea como clones promisorios o como futuros parentales para generar nuevas familias hibridas en zonas áridas, con un rendimiento de $900-1000 \mathrm{gr} / \mathrm{planta}$, con una producción temprana de tubérculos de buena calidad.

Las familias híbridas superiores que más destacaron por su performancia general agronómica fueron: MF-I x TS.5 (67.3\% de sob. y vigor 7.6), MF-1I x XY.13(83.5\% sob. y vigor 7.5), y la familia MF-1I x TS.13,( $46.4 \%$ sob. y vigor 7.4). En total, de estos tres híbridos superiores se seleccionaron 57 genotipos por la arquitectura ideal de la planta, tuberización temprana y hábito de crecimiento determinado. Los 57 genotipos o clones iniciales de papa fueron evaluados bajo condiciones de baja temperatura y días largos de verano en la sierra en Huancayo (3300 msnm). Sin embargo, durante la cosecha que se realizó en Huancayo, a los 90 días de la siembra, se observó una desadaptación casi total de estos clones a las condiciones de sierra y fotoperiodo largo. La mayoría mostró tubérculos pequeños y estolones muy largos, por lo que fueron descartados.
Es posible agregar otro factor de desadaptación de este grupo de clones: la intensa radiación solar de la sierra.

\subsubsection{Experimento TPS.2}

Con la finalidad de evaluar las alternativas de la producción comercial de papa a partir de semi la botánica en la zona semiárida y altoandina de Tarata a 3100 msnm y con alta radiación solar, se estableció dos experimentos. El primer se realizó durante la primavera-verano con dos poblaciones de tubérculos familias (ST), provenientes de TPS cosechados y seleccionados en La Molina - Lima, en suelos normales no estresados. El vigor del follaje observado fue moderado en ambas poblaciones ST: FK.69 × CEW.69, y serrana x TS.9. Durante la cosecha se observó una gran diferencia de producción de tubérculos en ambos híbridos. El híbrido CFK.69 x CEW 69.1 presentó mayor performancia agronómica, habiendo seleccionado 20 clones de un total de 150 sembrados. Del híbrido serrana $\times$ TS.9 de muy bajo rendimiento, solamente se pudieron seleccionar 7 clones de un total de 145 plantas o genotipos sembrados.

El segundo ensayo se realizó en plena temporada de verano y con riego adicional, debido a la escasa precipitación fluvial ( no mayor de $300 \mathrm{~mm}$ ). Se diseñó el experimento para determinar la performancia agronómica de 61 familias híbridas de TPS con genes de alta precocidad, resistencia a virus y a la rancha en la papa (Phytophthora infestans). Debido a la poca emergencia de plántulas en las bandejas de germinación, nueve familias fueron descartadas. La germinación y emergencia de las plántulas hasta llegar al tamaño de transplante $(+-10 \mathrm{~cm})$ fue de 50 días, es decir, 20 días más que en la costa, debido a las bajas temperaturas. El periodo de crecimiento fue de 90 días (20 enero-20 abril). Se observó un vigor moderado en el follaje de las familias y una gran variabilidad intra e interfamilias para la susceptibilidad al ataque del tizón temprano de la papa: Alternaria solani, el cual se presentó en la última etapa de desarrollo de las plántulas. Asimismo, a los 70 dias después del transplante hubo incidencia de heladas tempranas que afectaron un $30-40 \%$ de las plantas, acelerando su senescencia. De una población total de 5200 genotipos evaluados, se marcaron y seleccionaron 193 clones o genotipos promisorios. Las siete mejores familias que tuvieron una performancia agronómica moderada bajo éstos estreses y mostrando un vigor de 5-7, frente a los demás fueron: TS. $6^{\star} \times 104.12$. LB, TS. $11 \times$ 104.12.LB, TS. $14 \times 104.12$. LB, LT. $8 \times$ R.128.6, ATZIMBA x R.128.6, MF-II x 104.12.LB, y LT.8 x 104.12.LB. Los progenitores femeninos aportaron genes de gran precocidad y tolerancia al calor, en 
cambio los progenitores masculinos, como 104.12.LB, aportaron genes de resistencia a la rancha de papa (Phytophthora infestans). Estos resultados nos indican que la siembra y transplante de TPS en la zona altoandina, debería hacerse más tempranamente y en dos campañas agrícolas, es decir, octubre-diciembre y enero-marzo, con el mismo grupo de familias TPS para determinar su estabilidad. (Tabla $N^{\circ} 1$ )

\subsubsection{Experimento TPS.3}

En suelos no estresados y con alta tecnología de manejo del cultivo y bajo condiciones de mediana temperatura y fotoperiodo corto, en la estación experimental de La Molina-Lima, se evaluaron 53 familias híbridas TPS para el rendimiento y la calidad de los tubérculos a los 90 dias. En la cosecha se seleccionaron únicamente las tres familias de mejor rendimiento y uniformidad en los tubérculos. Estas familias seleccionadas: TS. $9 \times$ TPS. 67 , TS. $14 \times$ TPS 67 y TS.9 x XY.4, ya en forma de tubérculos ST de primera generación clonal fueron sembradas en las zonas áridas y suelos semisalinos de Pachía-Tacna, en un diseño experimental junto con el control vr. desiree. La mayor performancia agronómica, bajo condiciones de otoño con baja temperatura y fotoperiodo corto, fue observada en el híbrido TS. $9 x$ XY.4 con alta precocidad, vigor y rendimiento. Esta familia superó en rendimiento y calidad del tubérculo a la variedad desiree utilizada como control. Sin embargo, se observó un grado moderado de segregación para el tamaño del tubérculo. (Fig. $N^{\circ} 1$ )

\subsubsection{Experimento TPS.4}

Bajo condicones de baja temperatura y fotoperiodo corto en suelos áridos, con niveles moderados de salinidad y toxicidad de boro, se evaluó un total de 63 familias híbridas TPS a 900 msnm, Pachía- Tacna. Se detectó una variabilidad genética en relación al vigor del follaje que, en general, fue de medianó a alto.

Los estreses abióticos, moderados durante la conducción del experimento, incluidos el de riego ligeramente restringido y la ocurrencia del ataque temprano de Alternaria solani (tizón temprano), afectaron grandemente el rendimiento y calidad de los tubérculos en la mayoría de las familias hibridas evaluadas. Sin embargo, bajo estos estreses fue posible identificar cinco familias híbridas adaptadas a estas condiciones con buen rendimiento y calidad de tubérculos. Estas cinco familias: Atzimba x TPS.67, HPS I/113, TS. 14 x TPS. 67 , TS. 5 x TPS. 67 y TS 14 x 104.12.LB, superaron en rendimiento y calidad a la variedad desiree usada como control.

\subsubsection{Experimento TPS.5}

Un total de once familias híbridas de TPS fueron evaluadas en Las Vilcas- Tacna, a 550 msnm, bajo condiciones de baja y mediana temperatura y de dias cortos a días largos, en suelos áridos con niveles moderados de salinidad y toxicidad de boro. Alta segregación por la sobrevivencia promedio, fue observadad en las familias a los 30 días de evaluación después del transplante. Asimismo, se detectó una alta segregación entre familias para el vigor del follaje a los 80 días del periodo de crecimiento. Alta frecuencia de sobrevivencia, vigor del follaje y rendimiento de tubérculos fue mostrada por los hibridos TPS: MF I x TPS.67, I1035 x TPS.113, TS. 6 x TPS.113. Un total de 26 genotipos o clones promisorios de primera generación clonal fueron seleccionados para una evaluación más avanzada en rendimiento y sistema reproductivo en Tacna y Huancayo. ( Tabla $\mathrm{N}^{\circ} 2$ )

\subsubsection{Experimento TPS.6}

Bajo condiciones de fotoperiodo largo, alta temperatura en Calana-Tacna, a $650 \mathrm{msnm}$, se condujo un nuevo experimento con 42 familias hibridas de TPS, en suelos áridos con niveles medianos de salinidad, toxicidad de boro y riego ligeramente restringido. Un total de 2520 genotipos o plántulas agrupadas en 42 familias fueron evaluadas por su performancia agronómica general. Sin embargo a mediados del periodo de crecimiento de las plantas, se presentó un fuerte ataque de la nueva plaga Russelina solanicola (Ruselia o Cigarrita ploma) el cual produjo daños marcados al follaje, sobre todo a los brotes, limitando el desarrollo normal de las plantas. La aplicación continua de insecticidas químicos disponibles en el mercado local no fue efectiva en el control de esta plaga. A pesar de un ambiente favorable para el desarrollo del nemátodo (RKN) no se registró ataque en los tubérculos en ninguna familia ni en la variedad costanera usada como control. Solamente seis familias hibridas de un total de 42 fueron identificadas como tolerantes a estos estreses con rendimiento ligeramente inferiores a la vr. Costanera: TS. $9 \times$ XY.4, TS. $9 \times$ TPS.67, TS. $5 \times$ TPS. 113 , TS. $5 \times$ TPS. 67, TS. $14 \times$ TPS.67, TS. $14 \times$ TPS.13. (Tabla.3)

\subsubsection{Experimento TPS.7}

Un experimento demostrativo en chacra de agricultor, usando dos familias de tubérculos ST, fue conducida junto con el mismo agricultor, en suelos áridos con niveles bajos de salinidad y boro, riego normal, en Pachía-Tacna, a $1000 \mathrm{msnm}$. Casi todo el periodo de crecimiento estuvo comprendido en días cortos de invierno y baja temperatura. Estas dos familias fueron alternadas en el experimento con la variedad desiree. 
En general, el vigor de las plantas en ambos híbridos, asi como en la vr. desiree, y el control fueron marcadamente altos (9) y libres de sintomas de enfermedades viróticas. Sin embargo, durante la cosecha a los 90 días de la siembra, se observó una marcada diferencia. Las plantas del hibrido MF I $\mathrm{x}$ katahdyn mostraron una buena performancia agronómica en términos de rendimiento y uniformidad de tubérculos de valor comercial. El rendimiento del híbrido MF I x TS.5 fue muy bajo con un alta segregación por el tamaño y forma de los tubérculos. El rendimiento y calidad de desiree fue mayor que MF I x TS.5, pero menor que MFI x Katahdin. Un total de 40 clones promisorios parentales, fueron seleccionados para evaluaciones futuras en diferentes localidades.

\subsubsection{Experimento TPS.8}

Con la finalidad de demostrar al agricultor la alternativa de producir papa comercialmente, usando familias de tubérculos TS provenientes de semilla botánica TPS, se ensayaron con 17 familias, previamente seleccionadas durante el cultivo de primavera. Este ensayo fue conducido con la participación activa del agricultor, dueño de la chacra, en Pachía-Tacna a $1000 \mathrm{msnm}$. y en suelos áridos, con niveles bajos de salinidad y toxicidad de boro, en la época de invierno, con bajas temperaturas y fotoperiodo corto. En general, todas las familias híbridas mostraron un crecimiento acelerado y buen vigor del follaje, sin síntomas de enfermedades viróticas. Durante la cosecha realizada a los 90 días de la siembra, se identificó nueve familias muy promisorias con buena performancia agronómica en rendimiento y calidad comercial de tubérculos. Estas familias superaron en performancia la variedad precoz, desiree y al clon élite tolerante a estreses abióticos SDC 92.085 (Granola x $X Y .20$ ), ambos usados como controles, tal como se observa en la Tabla $\mathrm{N}$ ㄴ. Los híbridos que más destacaron y fueron comercializados por el agricultor fueron TS. $9 \times$ XY.13, TS. $9 \times X Y .4$, serrana $\times$ TS.5, 11035 x TS.5 y serrana $\times$ TS.5. (Tabla №4)

\subsubsection{Experimento TPS vs clon y variedad 1}

Tres familias de tubérculos TS seleccionados durante el invierno de familias TPS, fueron evaluadas junto con clones élites y variedades tolerantes a estreses abióticos, en chacra de agricultor, Calana-Tacna a 650 $\mathrm{msnm}$. Como control positivo fue usada la vr. desiree y como control negativo la vr. tomasa. El experimento fue conducido en BCR con cuatro repeticiones en suelos áridos con niveles moderados de sal y boro, con altas temperaturas de verano y fotoperiodo largo. A mediados del periodo de crecimiento de las plantas, se presentó un ataque del insecto Psílido russeliana solanícola que causó daños al follaje, mayormente en los brotes de los clones, variedades y genotipos susceptibles, es decir, se detectó variabilidad genética para susceptibilidad a russeliana. Las plantas susceptibles, además del daño al follaje, mostraron luego de dos a tres semanas del ataque, cierta clorosis, enrollamiento de hojas, enanimo y encrespamiento de las hojas y en muchos casos pigmentación de antocianinas en el borde de las hojas apicales. Estos síntomas parecen indicar que el insecto russeliana en un vector efectivo del micoplasma de la papa que actualmente está siendo integralmente investigada por el cientifico-virólogo, Dr. Luis Salazar, del Centro Internacional de La Papa. Alta frecuencia de genotipos susceptibles a russeliana fue detectada en la familia Aracy x TPS.113 y menor frecuencia en CEW $69.1 \times$ TPS.113, y alta frecuencia de resistencia en TS. $9 x$ TPS.67. Los clones élites resistentes a estreses abióticos que más susceptibilidad mostraron tanto a russeliana como al micoplasma fueron: SDC 92.085, SDC 92.023, SDC 92.140, y la vr. Tacna. Sin embargo, una moderada resistencia de campo a russeliana y al micoplasma fue detectado en los clones élites: SDC 92.132, SDC 89.315, y en las variedades: basadre, costanera, y primavera. (Tabla $\mathrm{N}^{\circ} 9$ )

\subsubsection{Experimento TPS vs clon y variedad 2}

Familias de tubérculos seleccionadas bajo condiciones de verano de familias TPS, en ambientes ligeramente estresantes, fueron tamizados para resistencia a sequia y salinidad con niveles medianos de boro tóxico junto con clones élites y variedades tolerantes al calor y a la salinidad. El experimento fue conducido con riego por exudación (cintas exudantes) en suelos franco-arenosos a nivel del mar, en la época de otoño-invierno, en la EEA La Yarada-Tacna. Un total de 100 genotipos (tubérculos) distribuidos en cuatro repeticiones fueron evaluados en las familias LT. $8 \times$ 104.12.LB y MF II x XY.13. El tercer grupo de familias estaba constituido solamente por 25 tubérculos-clones, cada uno previamente seleccionado de plantas promisorias de diferentes familias TPS, cosechadas durante el verano.

Los estreses abióticos edáficos y posiblemente el fotoperiodo corto, afectaron grandemente a todas las plantas o genotipos de las familia-tubérculos, incluso a los clon-tubérculos, de los cuales se seleccionaron cinco clones tolerantes a estreses abióticos y fueron descartados 20 por su susceptibilidad. Los clones seleccionados están siendo evaluados en Huancayo y Lima en su performancia agrónomica y sistema reproductivo. Se observó una amplia variación en rendimiento y calidad entre los clones élites y variedades tolerantes a estreses abiótcos. Los clones élites SDC 92.023 , SDC 89.315 y la variedad basadre 
fueron los que mostraron establidad en la tolerancia a los estreses edáficos, asimismo, el tamaño y forma de los tubérculos fueron clasificados como de alta calidad para la agroindustria. (Tabla $\mathrm{N}^{\circ} 5$ )

\subsubsection{Experimento TPS con microtubérculos}

Minitubérculos o tuberculillos de 1 a $1.5 \mathrm{~cm}$. de diámetro generados de 11 familias TPS en bandejas de plástico, bajo condiciones de invernadero, fueron sembrados directamente en el campo con la finalidad de determinar su potencial de desarrollo y rendimiento en suelos no estresantes y riego por gravedad. El experimento se condujo en la EEA La Villa, del valle de Moquegua, a $1400 \mathrm{msnm}$, alta radiación solar, alta temperatura y días largos. Las familias que presentaron mayor porcentaje de sobrevivencia y vigor del follaje (7-9) fueron MF II x TPS.13 (79\%), Atzimba x TPS.67 (79\%). Sin embargo, la familia TS.6 x TPS.13 mostró baja sobrevivencia a los 30 dias de la siembra (48\%) pero las plantas sobrevivientes alcanzaron un alto vigor ( 9 ) y ocupáron el primer lugar en el rendimiento y calidad de tubérculos por planta ( $350 \mathrm{~g} / \mathrm{p}$.), seguidos de la falmilia TPS. $7 \times 104.12$.LB $(73 \%)$ con 257 gramos por planta. Este experimento fue el primer intento de cultivar papa, usando microtubérculos libres de patógenos producidos en bandejas. En cada bandeja se pueden obtener cerca de 100 tuberculillos manejables para siembra directa en el campo. Es necesario seguir ensayando con nuevas familias híbridas superiores de TPS.

\subsection{PROSPECCIÓN FUTURA DE TPS EN ZONAS ÁRIDO-SALINAS}

Hasta ahora, los resultados promisorios de estos experimentos, muestran la factibilidad de la producción comercial para consumo y de semilla - tubérculo (ST) de papa a partir de TPS libre de enfermedades viróticas en zonas áridas con estreses abióticos bajos. Sin embargo, es necesario ampliar la base genética de las poblaciones TPS para tolerancia a estreses abióticos en zonas áridas y para fotoperiodos cortos y largos, así como altas y bajas temperaturas. Es necesario también ampliar la base genética para uniformidad de tamaño y forma, pues en general se ha detectado una segregación muy significativa dentro de cada familia, para los caracteres de tamaño y forma de los tubérculos. Esto ocurre con mayor frecuencia en familias TPS (seedlings) que en familias de tubérculos generados (ST) provenientes de TPS. Asimismo, es necesario identificar familias híbridas de TPS con moderada insensibilidad al fotoperiodo para su amplia adaptación y producción sostenida en el tiempo y el espacio.

Los clones élites parentales deberían tener una 66 habilidad combinatoria para precocidad, tolerancia al calor y a niveles moderados de salinidad y sequia, características particulares que determinarían la adaptación y cultivo comercial de papa a partir de TPS en las zonas agroecológicas áridas y desérticas del Tercer Mundo. La utilización de clones tetraploides parentales ( $2 n=4 x=48=A A A A)$, generados a partir de clones haploides $(2 n=2 x=24=A A)$ por poliploidización sexual con gametos $2 n$ o por medio de duplicación somática cromosómica para producir familias superiores TPS, se vislumbra como una nueva alternativa muy promisoria para la agricultura futura. Se seleccionarian clones élites tetraploides con excelentes atributos agronómicos y tolerantes a estreses abióticos. Estos clones serían haploidizados a un nivel diploide, mediante el uso de clones polinizadores e inductores de haploides,como el caso del clon inductor IVP 35, con la ayuda de marcadores genéticos de herencia simple que permitan identificar las progenies diploides provenientes de la madre tetraploide. En realidad, estos clones diploides generados por el fitomejorador, desde el punto de vista citogenético, son denominados dihaploides por tener dos sets o juegos de cromosomas básicos $X=12$ y tienen la fórmula cromosómica: $2 n=2 x=24=A A$. Se hipotetiza que los clones progenitores tetraploides generados por poliploidización de los diploides altamente seleccionados por sus atributos agronómicos, fisiológicos y por su remarcable homocigosis, tendrían el potencial genético de producir progenies híbridas uniformes y superiores de TPS. La variabilidad morfológica dentro de cada familia hibrida de TPS mostraría una mínima segregación fenotipica no detectable a simple vista, durante la cosecha en el campo del agricultor. Estos aumentarían el valor comercial de los tubérculos cosechados en un periodo vegetativo de 90 días.

La explosión demográfica es cada dia más alarmante en el Tercer Mundo, millones de personas sufren hambre o están desnutridos, esto se hace más dramático en los países asiáticos y africanos y menos en América Latina. Hay escasez de alimentos para una población de seis mil millones de habitantes que alimentar para el año 2000 y con un incremento constante de la tasa de crecimiento poblacional en el Tercer Mundo, la producción de papa a partir de semilla botánica mejorada es una buena alternativa.

\section{ADAPTACIÓN DE NUEVOS CLONES Y PROGENITORES SUPERIORES A ZONAS ÁRIDAS Y SALINAS EN DIFERENTES FOTOPERIODOS}

Un aspecto importante dentro de la estrategia del presente proyecto ha sido la selección de clones superiores tolerantes a estreses abióticos, de temprana 
tuberización, resistencia de campo a los virus más comunes por tres a cuatro generaciones clonales de campo, así como un alta resistencia de campo a las razas virulentas del nemátodo del nudo de raíz Meloydogine incógnita, M. javanica y $\mathbf{M}$. arenaria. En este sentido, la selección de clones tolerantes a estreses abióticos, con buenos atributos agronómicos, es llevada año tras año. Los híbridos de los cruzamientos de parentales tolerantes a estreses abióticos y con resistencia a virus y RKN son rutinariamente tamizados en diferentes estaciones y fotoperiodos del año. A la fecha se tiene doce clones superiores de una marcada estabilidad en performancia agronómica durante las cuatro estaciones del año (950 $\mathrm{g} / \mathrm{pl}$ ), habiendo mostrado una relativa insensibilidad al fotoperiodo. Este logro podría significar la producción sostenida de materia prima fresca durante todo el año en la costa peruana para la agroindustria (Chavez, 1995, Mendoza et al,1991).

En un intento de probar la resistencia de campo a virus de clones superiores con semilla de tercera a quinta generación, producida en zonas infestadas de áfidos, se realizó un experimento avanzado en chacra de agricultor. Desde el inicio del periodo vegetativo se observó los síntomas de virus en el follaje, habiendo detectado la resistencia de campo de los clones SDC 92.132, SDC 91.O19 y SDC 89.315. Los demás clones mostraron síntomas de virosis, principalmente de PVX, PVY y PLRV. Posiblemente, estos clones sean genotipos duplex (XXxx, YYyy) o triplex (XXXx, YYYy) para resistencia a PVX y PVY, y tengan una mayor frecuencia de genes menores para la resistencia al virus PLRV. Estos clones también combinan la alta calidad industrial, además de su alta precocidad (Chavez et al 1994).

Bajo condiciones de la sierra semiárida de Tarata (3100 msnm) y en días largos de primavera-verano se evaluaron un primer grupo de 30 clones avanzados, seleccionados por su tolerancia a suelos árido-salinos en la costa. Durante el cultivo experimental se presentó un fuerte ataque de Alternaria solani (seca-seca) que afectó el follaje de la parte inferior y media de las plantas. Durante la cosecha realizada a los 90 días de la siembra y en presencia de cerca de 20 agricultores de la zona se logró seleccionar solamente un clon superior SDC 92. 019 , con buen rendimiento y calidad del tubérculo en las cuatro repeticiones. A pesar que se descartaron 29 clones, los agricultores mostraron interés y entusiasmo por este clon y le bautizaron derramando chicha a los tubérculos con el nombre de tarateña. En enero de 1994 se establece nuevamente en Tarata (3100 msnm) un experimento avanzado con 16 clones élites precoces y tolerantes al calor y cuatro variedades locales utilizadas como control. Se logró la identificación de cinco clones adaptados a las condicones de la sierra peruana con los clones élites :SDC89.262, SDC89.315, SDC92.132, SDC92.145, SDC91.906, habiendo sido superado en rendimiento solamente por la variedad cica, en un periodo de 90 días. El descubrimiento de estos clones superprecoces para las condiciones de sierra peruana, permitirá el cultivo de papa en primavera y verano, asimismo, permitiría el establecimiento de un sistema sostenible de producción de semilla básica y certificada en la sierra para su comercialización y cultivo en la costa surperuana.

Bajo condiciones de días largos de verano, alta temperatura diurna y baja temperatura nocturna, se realizaron dos experimentos simultáneos en las zonas agroecológicas semiáridas de Ticaco (3300 msnm) y Tarata (3100 msnm), para determinar la performancia de 37 clones élites, incluidos los clones seleccionados anteriormente en otras zonas. La cosecha realizada a los 90 días de la siembra mostró el extraordinario rendimiento y calidad de tubérculos del clon SDC91.612 (basadre), junto con los seis clones élites, anteriormente mencionados. Estos siete clones mostraron entre buena y alta calidad para procesamiento industrial. (Tabla №6)

Durante el verano de 1995, se evaluaron 34 clones promisorios bajo condiciones de altas temperaturas en suelos áridos, medianamente salinos a $550 \mathrm{msnm}$ en Tacna. Estos clones fueron seleccionados, previamente, de un grupo de 240 clones, en suelos muy salinos bajo condiciones de invierno y por su calidad para procesamiento industrial y resistencia a los virus PVX y PVY. Durante la cosecha se identificó como el mejor clon SDC92.085, proveniente de un cruzamiento de GRANOLA por XY.20, con un rendimiento de $923 \mathrm{~g} /$ planta y de un excelente valor comercial, habiendo superado grandemente a las cuatro variedades usadas como control. El clon SDC92.085, hasta ahora ha mostrado en el tiempo y el espacio una estabilidad para calidad industrial, mas parece ser sensible a fotoperiodos cortos de invierno de la costa.

Bajo condiciones de verano-otoño se evaluó la performancia agronómica de 11 clones precoces y resistentes a estreses abióticos en suelos ligeramente salinos, intercalados con familias TPS. La semilla tubérculo utilizada fue de cuarta generación clonal producida en Tacna. El experimento fue conducido en Pachía a $1000 \mathrm{msnm}$. El follaje fue cortado a los 90 días después de la siembra. Durante la cosecha se determinó la gran performancia agronómica de los clones élites SDC91.640, SDC89.315, SDC91.906 y SDC91.612, los cuales superaron en rendimiento a los tres controles usados. Los clones SDC 91.906 y SDC 91.612 han venido mostrando a través de numerosos experimentos en chacra de agricultores, una consistente estabilidad en performancia agronómica 
general y una relativa insensibilidad al fotoperiodo y temperatura, por lo menos en suelos áridos de la costa media, entre 600 y $1000 \mathrm{msnm}$.

Se condujo un experimento en chacra de agricultor en la zona de Pocollay a $700 \mathrm{msnm}$ en suelos áridos ligeramente salinos, bajo condiciones de inviernoprimavera-1994. Se utilizaron 17 clones precoces élites $y$ tres variedades usadas como control. La cosecha y evaluación de rendimiento y calidad de los tubérculos fue realizada a los 100 dias después de la siembra. Seis clones mejorados SDC89.315, SDC89.262, SDC92.132, SDC92.640, SDC92.018 y SDC89.311, mostraron una extraordinaria precocidad y rendimiento con más de mil gramos de tubérculos por planta, habiendo superado a los tres controles utilizados: desiree, revolución y peruanita y aun a las variedades de alta calidad industrial tacna y costanera. En la misma localidad de Pocollay se evaluaron once clones mejorados bajo condiciones de otoño-invierno 1995. Se utilizaron las variedades desiree y revolución como controles. Se determinó mayor rendimiento en los clones SDC91.514 (944 g/p), SDC89.311 (889 g/p). Sin embargo, los clones SDC89.019 y la variedada tacna mostraron rendimientos moderados pero con tubérculos de alta calidad en forma y tamaño (grado nueve).

A una alta presión de selección fueron sometidos clones élites y variedades tolerantes a estreses abióticos en un ambiente de campo infestado con poblaciones de la mosca minadora Lyriomiza widobrensis, en suelos árido-salinos y días cortos de invierno, en La Yarada a $100 \mathrm{msnm}$. Se observó un fuerte ataque y daño al follaje que generalmente estuvo en rango de mediano a fuerte ( 5 a 9) que afectó finalmente al rendimiento. Sin embargo, se logró identificar al clon élite SDC 92.640 y a la nueva variedad maría tambeña con menos daño de Lyriomiza (Tabla №7). Durante la primavera de 1996, se estableció otro experimento con clones élites y avanzados en la estación experimental agrícola de la Fundación Perú, valle de Moquegua $1400 \mathrm{msnm}$. Se registró un fuerte ataque de poblaciones de la plaga de la papa relativamente nueva y desconocida de Russelianma solanicola (Psilido, cigarrita ploma). Esta plaga causó un fuerte daño al follaje y sobre todo a los brotes, limitando el desarrollo normal de la planta y reduciendo a menos de la mitad el area foliar. De los 21 clones o variedades evaluadas bajo fuerte ataque, se pudo identificar algunos que mostraron una tolerancia moderada a Russeliana y correlacionada al buen rendimiento del tubérculo. Estos clones élites son: SDC 91.628 y SDC 91640 y la variedad maría tambeña. Se observó un menor ataque de Russeliana en la variedad tardía tomasa, pero el rendimiento fue muy inferior. Parece indicar que las variedades o clones muy precoces y de mediana o poca área foliar son más susceptibles al daño causado por Russeliana solanicola. (Tabla $\mathrm{N}^{\circ} 8$ )

El análisis de los resultados de más de 70 experimentos de campo, conducidos en las cuatro estaciones del año en las zonas áridas de Tacna, Moquegua y Arequipa, nos indican diferencias genotípicas en la performancia agronómica general y en el rendimiento y calidad de tubérculos en particular de los clones mejorados por efecto del fotoperiodo y la temperatura. Esto se presenta especialmente a $18^{\circ}$ latitud Sur. Sin embargo, se ha logrado determinar nueve clones mejorados en las zonas áridas como SDC91.640 y SDC91.612 (basadre) que presentan una alta performancia agronómica en el tiempo y espacio, y son moderadamente insensibles a diferencias de fotoperiodo y temperatura. A la fecha se cuenta con 43 clones superiores de papa, adaptados a las condiciones áridas y salinas de la costa peruana, superprecoces y tolerantes al calor. La gran mayoria de los clones tiene alta calidad industrial para la elaboración de ojuelas, papa frita, papa semifrita congelada, almidón y harina. De este caudal de clones élites generados por este proyecto, siete presentan adaptación a condiciones semiáridas de la sierra a $3100 \mathrm{msnm}$. Asimismo, diez de estos clones ya han sido introducidos al sistema de cultivo in vitro y a pruebas serológicas (ELISA) para la detección y eliminación de virus. Esto favorecerá enormemente la producción de plántulas y tuberculillos libres de patógenos para la distribución nacional e internacional de semilla.

\section{PRESIÓN DE SELECCIÓN PARA TOLERANCIA A TOXICIDAD DE BORO}

En un estado avanzado del presente proyecto, cuando se determinó una considerable ganancia genética, se sometió a la gran mayoría de los clones mejorados de papa, a evaluaciones y tamizados para tolerancia a estreses de toxicidad de boro y sequia. Los niveles elevados de boro en las zonas áridas de la costa peruana, como el caso de los valles costeros de Sama y Locumba, donde alcanzan niveles tóxicos de 10 a 14 ppm. los cuales producen al igual que el estrés de salinidad, un efecto de crecimiento retardado, clorosis y quemadura del borde de las hojas de la planta de papa, así como enanismo y bajo rendimiento de tubérculos (Chávez et al 1995, 1994). Asimismo, el efecto nocivo del boro tóxico se presenta en clones avanzados, tolerantes a salinidad y sequía. Es por eso que el ensamblaje de estos tres atributos de resistencia a sal, sequia y toxicidad de boro, es necesario para la adaptación integral de los clones liberados a zonas agroecológicas áridas y salinas del trópico. En general, los clones avanzados de papa, tolerantes a salinidad y sequía, seleccionados para las zonas áridas y salinas, presentan una moderada tolerancia a niveles tóxicos 
de boro que fluctúan de 4 a 6 ppm. Los experimentos con clones avanzados de camote y tolerancia a niveles tóxicos de boro entre 4 y 12 ppm, en los valles de Sama, Locumba e Ite, muestran que existe una variabilidad genética, aunque en baja frecuencia, para tolerancia a la toxicidad de boro. Los experimentos con clones élites de papa todavía no se han realizado en estas zonas debido a la falta de semilla limpia y presupuesto para conducirlos.

\section{PRESIÓN DE SELECCIÓN PARA TOLERANCIA A SEQUÍA}

Se conoce que la disponibilidad de agua de regadío influye en el rendimiento de la papa,por eso es necesario una planificación adecuada del riego para optimizar el empleo del agua disponible en las zonas áridas. La vulnerabilidad de la papa ante los déficits de agua que ocurren durante su ciclo de crecimiento, trae como consecuencia bajos rendimientos y mala calidad de los tubérculos. Esto pone de manifiesto el papel importante que juega el agua en la producción comercial (Ekanayake, 1994). Sin embargo, la papa presenta variabilidad genética para resistencia a sequía, es decir, algunos clones o variedades se desempeñan mejor que otras bajo el estrés de sequía (Sinden y Webb,1974). Con criterios de selección asociados a la resistencia a sequía, se puede seleccionar y mejorar genotipos o clones adaptados a un medio agroecológico árido con estreses de sequía. El perjuicio que causa la sequía en la papa se ha descrito como consecuencia de:

a) La reducción del follaje productivo, escasa emergencia y escasa expansión foliar.

b) Reducción de la tasa de fotosíntesis por unidad de área foliar.

c) Reducción del periodo vegetativo o senescencia precoz.

d) Reducción del rendimiento de tubérculos por planta.

e) Disminución de la calidad de los tubérculos (deformaciones y grietas).

Ekanayake en 1994 planteó una escala de apreciación del estrés por sequía basada en la marchitez foliar. Esta escala se viene actualmente utilizando para identificar clones tolerantes a estreses moderados de sequía, desde el punto de vista de la producción de biomasa aérea. Sin embargo, durante la cosecha se aplica otra escala para la evaluación del rendimiento y calidad de los tubérculos y luego se trata de correlacionar ambos parámetros.

\begin{tabular}{|l|l|}
\hline ESCALA & DESCRIPCIÓN \\
\hline 1 & $\begin{array}{l}\text { No hay estrés de sequía, turgencia } \\
\text { total de todas las hojas en todas las } \\
\text { plantas del clon o familia. }\end{array}$ \\
\hline
\end{tabular}

\begin{tabular}{|l|l|}
\hline 3 & $\begin{array}{l}30 \% \text { de las hojas están marchitas ó } \\
30 \% \text { de la población de plantas se } \\
\text { ha marchitado. }\end{array}$ \\
7 & $\begin{array}{l}50 \% \text { de las hojas estan marchitas ó } \\
50 \% \text { de la población se ha } \\
\text { marchitado. } \\
80 \% \text { de las hojas están marchitas u } \\
80 \% \text { de la población se ha } \\
\text { marchitado. } \\
\text { Marchitez total y muerte de las } \\
\text { plantas. }\end{array}$ \\
\hline
\end{tabular}

La gran mayoría de los experimentos programados durante los últimos cuatro años fueron conducidos con riego moderademente restringido, a fin de seleccionar clones élites con moderada tolerancia a los estreses de sequía frecuente en las zonas áridas. El germoplasma mejorado de papa hasta ahora obtenido muestra esa tolerancia al riego restringido frente a otras variedades conocidas. Los parámetros utilizados para determinar el grado de resistencia o tolerancia a sequia fueron el grado de senescencia del follaje, el rendimiento de tubérculos por planta, la calidad de los tubérculos (forma y tamaño) y la calidad industrial para procesamiento, utilizando la escala de calidad (1-3-57-9).

En numerosos experimentos, conducidos con riego restringido, se ha observado que el estrés de sequia incrementa moderada o fuertemente la salinidad de las parcelas con estrés de agua, factor que hace un poco más complicada la interpretación de los resultados. En la mayoría de los casos, el vigor del follaje disminuye fuertemente a medida que se incrementaba el número de dias de sequía en los clones susceptibles. En general, el follaje verde y medianamente vigoroso muestra una correlación positiva con el buen rendimiento de tubérculos y la tolerancia a sequía. En este sentido, todos los clones avanzados de papa, tolerantes a salinidad, también han sido sometidos a estreses moderados de sequía o riego restringido, como parte de la estrategia para la adaptación general a zonas áridas, donde el recurso agua es escaso y restringido. Bajo condiciones de días largos y temperatura de media a alta, durante la primavera y verano de 1995 , se condujo un experimento con 14 clones de papa, en suelos ligeramente salinos, franco-arenoso limosos. El experimento fue dividido en dos parcelas, una con riego normal, cada ocho dias y la otra con estrés de sequía a partir de los 60 días, después de la siembra, con un periodo vegetativo de 90 días. La tolerancia a sequía fue determinada con el rendimiento y la calidad de los tubérculos por planta, así como la calidad industrial de hojuelas fritas. Los 
clones élites de buena performancia agronómica y calidad industrial bajo condiciones de estrés de sequía fueron: SDC 91.628, SDC 92.019, SDC 92.145 (desértica) y SDC 91.612 (basadre). En general, se observó un incremento de la calidad industrial de los clones con el riego restringido. La variedad tomasa tito condemayta, usada como control, ocupó el último lugar del ránking de rendimiento y calidad de tubérculos. Siete clones élites superaron en rendimiento a la variedad precoz y tolerante al calor bajo riego normal, sin embargo, la vr. desiree ocupó el tercer lugar en tolerancia al estrés de sequía y con buena calidad para procesamiento industrial. Esta presión de selección ha permitido en los numerososos experimentos obtener más de 20 clones élites con doble resistencia a tolerancia, salinidad y sequía. Es importante mencionar que estos clones élites tolerantes a sequia, con excepción de SDC 91.628, mostraron también adaptación a las condiciones semiáridas de la sierra de Tacna.

\section{BASES GENÉTICAS DE LA ESTRATEGIA DE ADAPTACIÓN Y AVANCE DE SELECCIÓN}

La principal estrategia genética en la adaptación de clones superiores para tolerancia a salinidad y otros estreses abióticos, relacionados a zonas áridas y salinas, es la generación o desarrollo de nuevas poblaciones por un sistema cíclico de selección recurrente que permita llegar a las siguientes metas:

1. Mantener una amplia diversidad y base genética para resistencia a estreses abióticos.

2. Incrementar los genes que controlan la precocidad y tolerancia al calor en papa.

3. Incrementar la frecuencia de genes que gobiernan la resistencia de campo al nemátodo del nudo de la raíz (Meloydogine).

4. Seleccionar familias TPS y clones parentales TPS superiores, adaptados a fotoperiodos cortos, largos e insensibles al fotoperiodo.

5. Incrementar la frecuencia de genes para la tolerancia o resistencia a sequía.

6. Generar clones parentales TPS con buena habilidad combinatoria para producir progenies con alta uniformidad de tamaño y forma de los túberculos (reducción del grado de segregación).

7. Buscar la combinación favorable de caracteres agronómicos deseables, con la calidad industrial en los nuevos clones e híbridos seleccionados.

8. Buscar la incorporación de genes de resistencia a plagas y enfermedades predominantes en zonas áridas en el germoplasma mejorado de papa .

9. Utilizar progenitores o parentales de buena habilidad combinatoria para tolerancia a estreses abióticos.
Comprendida dentro de la base genética, el rendimiento final de una planta tuberífera, como el caso de la papa, está determinado por la suma de la acción de un caudal de genes agrupados en tres categorias:

a) Los genes de rendimiento per se.

b) Los genes de adaptación.

c) Los genes de resistencia a plagas y enfermedades.

Enmarcado dentro de esta teoria, el presente proyecto se ha concentrado en el grupo de genes de adaptación, los cuales son mayormente poligénicos, y al final son los que determinan la adaptación de genotipos a los estreses abióticos, como la salinidad, calor, baja temperatura, sequía y toxicidad de boro y la sensiblidad a un determinado fotoperiodo y aun la precocidad. En este sentido, la generación y desarrollo de una familia TPS élite o de un clon élite con gran potencial de rendimiento, es el resultado principalmente de una combinación favorable de los genes aditivos y epistáticos (Thompson y Mendoza, 1984).

Para el desarrollo de nuevas poblaciones se ha venido realizando cruzamientos dirigidos en papa, utilizando mayormente los diseños genéticos I y II, entre plantas de progenitores debidamente seleccionados, mediante pruebas de progenie (Thompson et al 1983). Las pruebas de progenie son de gran valor en la selección de progenitores, ya que no es suficiente que un clon élite o superior, candidato a progenitor, muestre excelentes atributos fenotípicos o agronómicos, sino que es más importante que una proporción significativa de la descendencia de este clon élite muestre los atributos agronómicos deseables, heredados de sus progenitores. Contando con este tipo de materiales parentales se puede lograr un progreso sostenido dentro de la selección recurrente. En este sentido, se ha venido ensayando la generación y evaluación correspondiente de familias dialélicas para resistencia a estreses abióticos, así como parentales masculinos y femeninos con buena habilidad combinatoria para resistencia a sequía y salinidad.

La especie más cultivada de papa, Solanum tuberosum $(2 n=4 x=48=A A A A)$, es un cultivo de naturaleza alógama, autopoliploide, con un sistema de herencia tetrasómica, mostrando rápidamente en las primeras generaciones los efectos perniciosos de la depresión de endocría al ser autoclonizado. Los resultados de mejoramiento genético, mediante la aplicación de diseños genéticos madre-progenie han sido muy favorables. La información genética disponible sobre papa y camote, indica que el método de selección recurrente, con los diseños genéticos I y II, es la ruta más adecuada para seguir en el mejoramiento para tolerancia o resistencia de estreses abióticos. Este 
método permite aprovechar al máximo la acción genética aditiva, de dominancia y epistática, que en suma determinan el rendimiento final de la planta tuberífera.

\section{CULTIVO IN VITRO DE LOS CLONES SUPERIORES TOLERANTES A ESTRESES ABIÓTICOS}

La mayoría de los clones superiores élites y aquellos considerados candidatos para ser futuras variedades, antes de ser liberados fueron sometidos al sistema de cultivo in vitro para la limpieza de virus y otros patógenos como hongos, bacterias y micoplasmas (Tabla №10). Este proceso generalmente toma dos años de trabajo e involucra varias etapas, desde la selección del material inicial hasta la producción de tuberculillos (semilla pre-básica I). El desarrollo de cada una de las etapas del sistema de cultivo in vitro, demanda personal especializado en biotecnología vegetal. A continuación se detalla panorámicamente cada una de las etapas del sistema utilizado (Roca et al,1990).

\subsection{SELECCIÓN DEL MATERIAL INICIAL}

La selección del material se inicia desde el campo de cultivo experimental. Entre todas las plantas del clon en estudio, se selecciona la planta más sana, vigorosa y sobre todo de una morfología representativa, cuyos descriptores morfológicos, fisiológicos y reproductivos corresponden exactamente a las descripciones originales registradas del clon o variedad. Durante la cosecha se selecciona únicamente un solo tubérculo de la planta marcada. Este tubérculo tiene que ser representativo del clon o variedad y sus caracteres morfológicos y anatómicos (cortes de la pulpa) corresponden exactamente a los registros originales. Este tubérculo seleccionado es ligeramente tratado con desinfectantes y brota en forma natural sin la aplicación de promotores químicos de ruptura de latencia. Esto se hace para evitar cualquier alteración en la estructura genética o una mutación somática en el material inicial.

\subsection{TERMOTERAPIA Y MICROTERMOTERAPIA}

El tubérculo seleccionado con brotes robustos es sembrado en un macetero con substrato de vermiculita o musgo esterilizado en un invernadero a prueba de áfidos. Una vez que emergen los brotes y desarrollan los tallos hasta un tamaño de $15 \mathrm{a} 20 \mathrm{~cm}$. de altura se poda la parte apical de los tallos para promover la formación de ramas laterales. Después de podar los tallos con tijera esterilizada se coloca el macetero en la cámara de termoterapia para generar el rápido crecimiento de ramas laterales a partir de los brotes axiliares. Esto se logra dentro de la cámara con alta temperatura y gran intensidad lumínica (5000 unidades luz). La temperatura diurna es de $36^{\circ} \mathrm{C}$ durante 16 horas y la temperatura nocturna es de $28^{\circ} \mathrm{C}$ durante 8 horas. A partir del quinto al décimo dia, desarrollan ramas laterales delgadas y alargadas por efecto de la intensa iluminación y alta temperatura. Este proceso es muy importante y crítico, ya que se quiere que la parte extrema y apical de los tallos denominados ápices meristemáticos se encuentren libres de virus, debido a que la multiplicación y alargamiento del tejido vegetal sea más rápido que los virus presentes en los tejidos inferiores del tallo.

Es necesario mencionar que últimamente se viene desarrollando con éxito el nuevo método de MICROTERMOTERAPIA que consiste en someter plántulas in vitro medianamente desarrolladas, a termoterapia bajo altas temperaturas $\left(36^{\circ} \mathrm{C}-28^{\circ} \mathrm{C}\right)$ e intensidad lumínica (5000 lux).

\subsection{EXTRACCIÓN Y CULTIVO IN VITRO DE LOS MERISTEMOS}

De la cámara de termoterapia se muestrean brotes apicales de las ramas alargadas de 5 a $10 \mathrm{~mm}$. de longitud. Estos brotes son esterilizados en una placa petri de vidrio dentro de la cabina de flujo laminar con alcohol y cloro (5\%) durante 1 minuto. Con la ayuda de un microscopio estereoscopio binocular y de buen aumento se procede a extraer los ápices o tejidos meristemáticos apicales de 0.5 a $1.0 \mathrm{~mm}$ de longitud. Estos meristemos se inoculan individualmente en tubos de vidrio No 25 con el medio de cultivo a base de MS.y vitaminas. Una vez que el meristemo inoculado ha desarrollado, para formar un tallo o planta normal, se hace la micropropagación en otros medios de cultivo más adecuados para el desarrollo de plántulas normales (MS más hormonas de crecimiento). Duplicados de las plántulas clonadas son transferidas a maceteros con sustrato esterilizado para el desarrollo de plántulas normales bajo condiciones aisladas en invernadero o cámaras de crecimiento. (Figs. №2a, 2b.)

\subsection{PRUEBAS ELISA PARA DETECTAR LA PRESENCIA DE VIRUS}

Una vez obtenidas las plantas normales e incluso tubérculos de las plántulas in vitro, se realiza las pruebas ELISA del follaje o de los tubérculos brotados con la finalidad de detectar con precisión la presencia de los virus más comunes de la papa, los cuales son: PVX, PVY, PLRV, PVS, APLV, APMV. El material genético en tratamiento es clasificado como libre de virus, si todas las seis pruebas de ELISA resultan ser negativas. Una vez logrado esto se procede a la micropropagación masal del material in vitro almacenado en la cámara de crecimiento para su distribución nacional e 
internacional. Además de estar libre de virus, este material se encuentra libre de hongos y bacterias, pudiendo de esta manera satisfacer las demandas decuarentena internacional.

Hoy en día, se cuenta con equipos o kids de ELISA portátiles para realizar pruebas de virus en cualquier laboratorio de biotecnología.

\subsection{TRANSPLANTE DE PLÁNTULAS IN VITRO AL INVERNADERO}

Como producto de la micropropagación masal se obtienen plántulas in vitro desarrolladas, las cuales a partir de 30 a 40 días de crecimiento después de la inoculación, son transplantadas primero a bandejas con sustratos esterilizados a base de musgo y arena fina. Luego de 10 a 14 días de desarrollo, estas plántulas son transplantadas a las camas de invernadero con sustratos de musgo, arena y humus de lombriz de tierra para su desarrollo y producción de tuberculillos libres de virus de primera generación clonal, denominada por los semilleristas de papa como semilla pre-básica-I. Los clones élites generados en el presente proyecto se encuentran hoy almacenados en el Banco Internacional de Germoplasma in vitro de papa del CIP y en el laboratorio de biotecnología-sección papa de la Universidad Nacional de Tacna. Después de la obtención de plántuias in vitro, fueron liberados conjuntamente para la agricultura nacional por la Universidad Nacional de Tacna, el Centro Internacional de la Papa y La Comunidad Económica Europea del proyecto Majes. Duplicados de plántulas in vitro que pasaron las pruebas de ELISA (negativos) para los principales virus de la papa, fueron enviados por el CIP a la Universidad Nacional de Tacna para su conservación y micropropagación masal.

\section{RESISTENCIA A ALGUNOS EStRESES BIÓTICOS PREDOMINANTES EN ZONAS ÁRIDAS}

El la zona agroecológica árida de la costa peruana el cultivo comercial sostenido de variedades mejoradas tolerantes a estreses abióticos no tendría el éxito esperado si el germoplasma mejorado es susceptible a los estreses bióticos más comunes o predominantes de la costa. En este sentido, dentro de la estrategia de mejoramiento y adaptación de clones élites se ha logrado la obtención de algunos clones con potencial de rendimiento y con resistencia al nemátodo del nudo de la raíz Meloydogine, así como a los virus más comunes de la papa.

\subsection{RESISTENCIA DE CAMPO A NEMÁTODOS}

El estrés biótico edáfico más importante en el cultivo de la papa, en zonas áridas y salinas de la costa peruana, es el ataque del nemátodo del nudo de la raíz, constituido por las poblaciones de tres especies, M.incógnita, M.javanica y M.arenaria. Durante la cosecha y evaluación de los experimentos de papa en el campo, los genotipos o clones susceptibles a estas plagas son eliminados en el programa de mejoramiento y adaptación. La indicación de susceptibilidad de la papa a Meloidogyne incluye nodulaciones en la raíz, necrosis, producción masal de huevos o quistes, rajaduras o deformaciones del tubérculo, clorosis y crecimiento retardado o enanismo y principalmente la reducción del rendimiento. Por eso es importante que cualquier clon mejorado o variedad de papa liberada, sea resistente a las razas virulentas de Meloidogyne. Estas tres especies de Meloidogyne parecen producir un sinergismo en el ataque a los cultivos de papa en la costa peruana (Jatala, 1978).

Investigaciones previas indican que la resistencia al nemátodo del nudo de la raíz es multifactorial. La selección de los genotipos parentales para cruzamientos se basa en la combinación de caracteres asociados a alto rendimiento, buena calidad comercial de tubérculos, tolerancia al estrés abiótico de sequia y salinidad y resistencia a Medaloidogyne. Jones y Dukes (1980) plantearon la hipótesis de que existen factores genéticos comunes que controlan la resistencia a estas tres especies de Medaloidogyne. Por otra parte, los estimados de heredabilidad para la reacción a estas especies son altos. Asimismo, la frecuencia de resistencia a las pruebas de progenie indican que el desarrollo de variedades resistentes a ambas especies sería relativamente fácil. Sin embargo, será necesario seleccionar para cada especie en forma independiente (Jones y Dukes 1980). La experiencia en la costa surperuana nos muestra que el nivel de la población de nemátodos, llega al máximo durante los meses de primavera y verano; es por eso que el tamizado óptimo de progenies y clones promisorios de papa se debe hacer entre noviembre y marzo a altitudes inferiores a 500 m.s.n.m. Los clones de papa antes de ser tamizados deben tener previamente resistencia genética al calor. Sin embargo, se han obtenido tamizados satisfactorios de poblaciones de papa y camote en la costa surperuana en primavera media y tardia, y en otoño temprano y medio. Esto se recomienda para clones de papa que no son tolerantes al calor de verano y a fotoperiodos largos.

En cada experimento de papa realizado en las zonas áridas con poblaciones nuevas de papa, los clones son tamizados para resistencia al nemátodo. Durante la cosecha de cada experimento de papa, se selecciona primero, en el campo, los clones para su performancia agronómica general, basada mayormente en el rendimiento y calidad de los tubérculos y luego en esta 
población seleccionada, se hace el tamizado y descarte de clones susceptibles al nemátodo. Asimismo se ha logrado seleccionar progenitores con buena habilidad combinatoria para resistencia a esta plaga.

\subsection{RESISTENCIA DE CAMPO A LOS VIRUS MÁS COMUNES}

Las enfermedades viróticas ocasionan grandes pérdidas de rendimiento a la papa. Las plantas infectadas con virus producen tubérculos más pequeños que las plantas sanas. Estos tubérculos, al ser empleados como semilla, en las siguientes campañas generalmente producen plantas infectadas, contribuyendo a una degeneración progresiva y total del cultivo. Se conocen aproximadamente unos 25 virus diferentes y un viroide que infecta la papa en condiciones naturales.Los virus causan diferentes síntomas en hojas, tallos, tubérculos, entre ellos mosaico, amarillamiento, moteado, necrosis, enrrollamiento de hojas y deformación del tubérculo. Estos síntomas son producidos mayormente por los virus más comunes de la papa como son: PVX, PVY, PLRV, PVS, APMV y APLV ( Salazar 1996). Cerca de diez especies de áfidos han sido identificados en los valles de Tacna y Moquegua que habitan mayormente en especies (8) de malezas halófilas muy comunes, que sirven como hospederos (Guerra C y R.Zegarra, 1993). Por otra parte, poblaciones de áfidos son detectadas en los cultivos y terrenos abandonados de papa, camote, aji, algodón, maíz y tomate. Esto origina una fuerte presión de población a los nuevos cultivos de papa, produciendo una efectiva infección a los clones sometidos a evaluación para resistencia de campo a virus.

Se ha observado que cualquier variedad o clon avanzado (que no es resistente a virus) cultivado en la costa surperuana (Tacna, Moquegua y Arequipa), muestran síntomas de enfermedad virótica en la siguiente campaña, reduciendo el vigor y el rendimiento, mostrando una "degeneración" en la variedad. Al igual que el daño causado por el nemátodo, una variedad superior o familia TPS adaptada a las condiciones de aridez, salinidad, calor y con buenos caracteres agronómicos, no tendría durabilidad ni futuro si no tiene resistencia a los virus más comunes, en un medio agroecológico con alta infección virótica. Este criterio no sólo es para la costa sino para la sierra semiárida del sur del Perú. En este sentido,uno de los mayores logros del proyecto de mejoramiento genético en papa para el Tercer Mundo, ejecutado por el departamento de Genética y Mejoramiento del Centro Internacional de la Papa, ha sido la transferencia de genes de resistencia a los principales virus de la papa a clones superiores. De esta manera, se ha logrado generar clones mejorados, inmunes a los virus PVY y PVX y clones resistentes al virus PLRV.En este sentido, el germoplasma mejorado de papa para zonas áridosalinas involucra también algunos clones inmunes a PVY y PVX y resistencia de campo al virus del enrrollamiento de la hoja PLRV.

Durante los últimos seis años se ha sometido a 38 clones élites de papa, resistentes a estreses abióticos, a una fuerte presión de selección para resistencia a virus.Los clones fueron cultivados experimentalmente en chacras de agricultores durante tres, cuatro y hasta cinco generaciones clonales, sin reciclar la semilla en la sierra ni en invernaderos, es decir, se utilizó la misma semilla. La observación de los síntomas generados por los virus en papa, en los clones élites comparados con las variedades convencionales, se realizó en cada campaña. Se identificó 16 clones de alta resistencia de campo a los virus del mosaico PVX, PVY y cuatro clones altamente resistentes a los seis virus comunes, PVX, PVY, PVA, APMV, y APLV. Por otra parte, las variedades convencionales usadas como control: revolución, mariva, tomasa y perricholi, mostraron alto grado de infección después de la 2 da y 3ra. generación clonal de campo bajo condiciones de costa.

A pesar de estos logros, hoy en día estamos encarando un nuevo problema fitosanitario con las poblaciones de la nueva plaga de papa surperuana llamada Cigarrita ploma (Russeliana solanicola) la cual además de producir daños al follaje, especialmente a los brotes, es un posible vector y transmisor eficaz de un fitoplasma de la papa (antes llamado micoplasma). Las observaciones preliminares realizadas de la insidencia de ésta enfermedad en la costa surperuana de Arequipa, Moquegua y Tacna, sugieren la existencia de una variabilidad genética para resistencia o susceptibilidad al fitoplasma en el germoplasma mejorado de papa, involucrando familias TPS, genotipos dentro de cada familia, clones élites y aun en algunas variedades liberadas.

\section{GANANCIA GENÉTICA}

Hasta ahora los resultados de la evaluación de clones mejorados para tolerancia a suelos árido-salinos, ilustran el potencial que tiene el cultivo de la papa para adaptarse a suelos marginales, desérticos, donde hay poca disponibilidad de agua de riego. Desde inicios de 1985 hasta el verano de 1997 , se han evaluado, bajo condiciones árido-salinas y en diferentes fotoperiodos más de 40,000,00 híbridos avanzados de papa. Como resultado de esta investigación, se han seleccionado 35 clones élites de papa, tolerantes a salinidad y sequía y de caliadad industrial. Asimismo, se han identificado cerca de 18 familias superiores TPS que muestran una tolerancia moderada a los estreses abióticos más 
comunes de las zonas áridas. Esta adaptación ha sido verificada en varios experimentos bajo condiciones de primavera, verano, otoño e invierno en la costa surperuana. Estos genotipos y familias TPS promisorios, sobreviven bajo condiciones de salinidad y riego restringido, mientras que otros sucumben a estos estreses.

La adaptación a estas condiciones edáficas, también implica la tolerancia a toxicidad de boro y otros estreses diferentes a la salinidad, tales como deficiencias en nitrógeno, fósforo y zinc, propios de los suelos desérticos del sur del Perú. De estos 35 clones élites, 10 han sido introducidos al sistema de cultivo in vitro para su limpieza de virus, micropropagación y distribución a los sectores productivos del país y del extranjero. Los clones élites y familias TPS tolerantes a salinidad y sequía, han mostrado rendimientos de 20 a 25 T/há, aun bajo condiciones de calor primavera y verano, y en un ciclo vegetativo de 90 , fluctuando la salinidad del suelo irrigado durante el crecimiento de la papa de 5 a $15 \mathrm{mmh} / \mathrm{cm} 2$ en los clones élites y de 4 a $7 \mathrm{mmh} / \mathrm{cm} 2$ en familias TPS. Asimismo el germoplasma mejorado ha mostrado una ganancia genética en la resistencia de campo a las razas virulentas del sur del nemátodo del nudo de la raíz, Meloidogyne incógnita, M. javánica y M.arenaria. Este material genético, mejorado de papa está siendo cultivado en áreas y estaciones climáticas no tradicionales, donde la producción comercial de estos cultivos sería casi imposible, sin la previa tolerancia genética a la salinidad y otros estreses edáficos propios del desierto.

Otros caracteres agronómicos comunes de este germoplasma mejorado, son también su gran precocidad y rangos altos de materia seca que lo hacen promisorio para procesamiento industrial. Todos los clones mejorados de papa son tolerantes al calor, debido a que las evaluaciones y selecciones han sido realizadas bajo condiciones de primavera tardía y verano. Además de estos atributos de adaptación, las variedades de papa desértica tienen excelente calidad industrial que las hacen potenciales para la agroindustria mediante un suministro sostenido durante todo el año de materia prima. En este sentido, la Universidad Nacional de Tacna y el Centro Internacional de la Papa, en forma conjunta, han liberado las mejores variedades superiores de camote y papa, adaptadas a esta zona agroecológica, común de la costa peruana. Durante los dos últimos años ha habido también una fuerte participación en el proyecto del convenio ALA-93 de la Comunidad Económica Europea en MajesArequipa, catalizando el avance de selección y diseminacion de los clones élites de papa de calidad industrial.

\section{SELECCIÓN IN VITRO PARA RESISTENCIA A SALINIDAD}

Pruebas experimentales in vitro con diez clones avanzados de papa, han mostrado una correlación moderada entre la resistencia a salinidad en el campo y la resistencia a salinidad bajo condiciones de cultivo in vitro. Clones que tienen buena performancia agronómica bajo condiciones edáficas de salinidad hasta $12 \mathrm{mmhs}$, no sobreviven o se muestran latentes bajo condiciones in vitro a una concentración de 12 mmhs. La formación de callos en plantas y clones sobrevivientes, parece ser un indicativo de reacción de resistencia al fuerte esrés de salinidad. Una de las limitaciones en los tamizados para resistencia a salinidad o toxicidad de boro, bajo condiciones de cultivo in vitro, son las diferencias clonales de respuesta al cultivo in vitro. Algunos clones de papa y camote presentan dificultades para su crecimiento y micropropagación. Los resultados de la experimentación sugieren un tamizado poblacional práctico, para resistencia a salinidad bajo condiciones de cultivo in vitro debería ser entre 6 y 8 mmhs.

\section{MECANISMO DE RESISTENCIA GENÉTICA AL ESTRÉS ABIÓTICO}

Las diferencias genotípicas en la tolerancia a estreses abióticos, producidas por la salinidad y toxicidad del boro, se deben a la variabilidad genética en el grado de eficiencia de absorción y transporte de los iones en la planta. En este sentido, la tolerancia a la salinidad y toxicidad de boro, así como el estrés de sequía, son poligenéticamente controlados. La reacción a salinidad en papa y camote no es simple. Generalmente hay una correlación negativa entre tolerancia al calor y sequía con la tolerancia al frío. Por consiguiente, clones selectos para buena performancia en calor y sequía, no tienen buena performancia en frío y viceversa. El mecanismo de tolerancia de las plantas de papa a la salinidad, se debe a la resistencia de cambio en la ultra estructura de los cloroplastos de las hojas de la planta por el estrés de la sal que presumiblemente afectan a la performancia de asimilación y capacidad fotosintética de la planta y a la producción de carbohidratos. Asimismo, a la habilidad de las células de la planta a tolerar altos niveles de sodio.

El mejoramiento genético para tolerancia a salinidad, ha sido llevado a cabo exitosamente en otros cultivos. Bains y asociados (1971) encontraron que las líneas mejoradas de cebada, tolerantes a salinidad, tenían una reducción de $39 \%$ del rendimiento, cuando se aumentaba la salinidad de 8 a $34 \mathrm{mmhs} / \mathrm{cm}^{2}$. Bains desarrolló variedades de cebada que pueden ser irrigadas con agua de mar, con un rendimiento del $50 \%$ menor que el promedio nacional de la India. Epstein y 
C.Rick en (1976) y Rick (1982) reportaron la tolerancia a salinidad de híbridos interespectivos de tomate, que puedan dar frutos aceptables con $33 \%$ de agua de mar.Epstein (1980) planteó la hipótesis de que la resistencia a salinidad en el tomate está asociada a la habilidad de las células a tolerar altos niveles de sodio o translocación de los mismos. Epstein y Lauchli (1980) plantearon la hipótesis de que las diferencias a la captación o ingreso de iones, así como el transporte de ellos, es importante en el mejoramiento para tolerancia a la sal.

A.Quinn, 1980, reportó la selección de variedades de remolacha azucarera, tolerantes a salinidad para las zonas áridas de Estados Unidos. Quinn, 1980, planteó la hipótesis que el mecanismo de resistencia a salinidad es debido a la exclusión selectiva de iones de sodio. De igual manera, se puede enumerar ejemplos de tolerancia a salinidad en variedades mejoradas de caña de azúcar y arroz en el sudeste de Asia tropical.

Analizando los planteaminetos de Pomannperoma (1982) y de Epstein y Lauchli (1980), podemos concluir que las diferencias genéticas en la tolerancia al estrés edáfico, producido por la salinidad, acidez, toxicidad de boro, aluminio y hierro, se deben a la variabilidad genética de la especie cultivada en relación a cinco factores principales:

1. La capacidad de absorción de iones por la raíz.

2. La traslocación de los elementos dentro del xilema.

\begin{tabular}{|l|l|}
\hline CLASE & $\begin{array}{l}\text { REACCION FENOTÍPICA DE LA } \\
\text { PLANTA }\end{array}$ \\
\hline 1 & $\begin{array}{l}\text { Sucumbe al ser trasplantada. } \\
\text { Emerge y sobrevive mostrando un } \\
\text { enanismo y clorosis } \\
\text { Desarrollo de la planta, mostrando } \\
\text { quemaduras en los bordes de las } \\
\text { hojas y ninguna o muy poca } \\
\text { tuberización. } \\
\text { Desarrollo normal y vigoroso del } \\
\text { follaje, pero muy poca o ninguna } \\
\text { tuberización. } \\
\text { Desarrollo escaso del follaje y } \\
\text { tuberización normal. } \\
\text { Desarrollo vigoroso del follaje y } \\
\text { tuberización normal. } \\
\text { Muestra una temprana senescencia } \\
\text { antes de los 70 días. } \\
\text { Acumulación de glicoalcaloides en } \\
\text { los tubérculos. }\end{array}$ \\
\hline
\end{tabular}

3. La retención de los iones en los tejidos adyacentes. 4. La movilidad de los elementos del floema.

5. La eficiencia en la utilización del metabolismo de iones.

Correlacionando estos principios, podemos decir que una plántula o un tubérculo brotado de papa plantada en suelos salinos, generalmente presenta los siguientes cuadros:

Dentro de la estrategia del proyecto, los clones promisorios seleccionados han sido de clase 5 y 6 . La primera permite una mayor densidad de siembra y mayor rendimiento. La segunda (clase 6) permite una cobertura rápida y eficaz del suelo, con el consiguiente ahorro de humedad edáfica y fluctuación moderada de los niveles tóxicos de salinidad.

\section{LIBERACIÓN DE VARIEDADES MEJORADAS DE PAPA DE CALIDAD INDUSTRIAL}

Las características agronómicas generales de las variedades superiores de calidad industrial liberadas para la agricultura de la costa peruana, han sido estudiadas y se mencionan a continuación. Sin embargo, es necesario una caracterización isoenzimática con amplio polimorfismo para una identificación precisa ("huella genética") de clon liberado.

a) Tolerancia a los factores adversos de muchos suelos de la costa, tales como salinidad (6-13 mmh), niveles moderados de boro (5-10 ppm.) y sequía parcial (riego restringido).

b) Potencial de rendimiento mayor de $20 \mathrm{tn} / \mathrm{há}$ en un periodo vegetativo de sólo 90 días.

c) Resistencia en campo al nemátodo del nudo de la raíz Meloydogine incógnita, M.javánica y M.arenaria, el cual es una plaga común que ataca a las plantas tuberíferas de la costa peruana.

d) Alta tolerancia al calor, tanto de primavera como de verano. Este atributo los hace condidatos para su cultivo en trópico medio y bajo, junto con algunas especies tuberiferas como la Xanthosoma y la Colocacia (Fig. N5), (Buso 1990)

e) Resistencia a los virus del mosaico de la papa PVX y PVY, al virus del enrollamiento de la hoja (PRLV), muy comunes y virulentos en el extremo sur de la costa peruana.

f) Buena y excelente calidad industrial para procesamiento.

XIV. VARIEDADES SUPERIORES DE PAPA DE CALIDAD INDUSTRIAL DISPONIBLES PARA ZONAS ÁRIDO-SALINAS DEL PERÚ: CARACTERÍSTICAS ESPECIALES. 


\subsection{VARIEDAD "COSTANERA"}

\section{Código Experimental : : LT-8 (CIP 379706.27) \\ Pedigree \\ LT-1 X XY.bulk}

El clon LT-1 utilizado como progenitor femenino posee una amplia adaptación en las zonas del trópico húmedo medio, muy buena tolerancia al calor, gran precocidad y tolerancia a la marchitez bacteriana. El progenitor masculino $X Y$ bulk proviene de una mezcla de polen de clones inmunes a los virus $X$ y $Y$. Ambos progenitores fueron desarrollados por el departamento de Genética y Mejoramiento del Centro Internacional de la Papa.

Características de la planta:

$\begin{array}{ll}\text { Vigor } & : \text { Bueno. } \\ \text { Altura } & : 60 \mathrm{~cm} . \\ \text { Nro de tallos } & : 4-5 \text { por planta. } \\ \text { Hojas } & : \text { Verde claro con foliolos } \\ & \text { medianos. } \\ \text { Pubescencia } & : \text { Escasa. } \\ \text { Flores } & : \text { Blancas. Floración escasa. } \\ \text { Bayas } & : \text { Muy escasas o ninguna. }\end{array}$

Características del tubérculo:

\section{Estolones}

Forma

Tamaño

Color de la piel

Color de la pulpa

Ojos

Brotes

Nro. de tubérculos

Periodo de latencia : Corto (6 semanas).

\section{Calidad del tubérculo:}
Materia seca
$21.6 \%$.
Azúcar reductor
$0.05 \%$.
Calidad de hojuelas :
Color de hojuelas
Muy buena.
Calidad de fritura
Muy bueno (1.2).
Muy buena.

\section{Resistencia a plagas y enfermedades}

Inmune a los virus $X$ y $Y$, moderadamente resistente a PLRV y al nemátodo del nudo de la raíz, Meloidogyne incógnita, tolerante a marchitez bacteriana y moderadamente susceptible a los tizones temprano y tardío.

\section{Resistencia a estreses abióticos}

$\begin{array}{ll}\text { Salinidad } & \text { : Media ( } 4-6 \text { mmhs). } \\ \text { Sequia } & : \text { Media ( riego restringido). } \\ \text { Calor } & \left.: \text { Alta (Prom. } 23-25^{\circ} \mathrm{C}\right) . \\ \text { Toxicidad en boro } & \text { : Baja }(4-8 \mathrm{ppm}) .\end{array}$

\section{Periodo vegetativo}

Muy precoz, 80-90 días.

\section{Adaptación}

Costa peruana, trópico humedo medio y bajo y sierrra media.

\section{Época de siembra}

Por su tolerancia al calor se adapta para su cultivo en primavera, verano y otoño. Sembrar a principios de setiembre (primavera-verano) y a principios de marzo (otoño).

\subsection{VARIEDAD "TACNA"}

\section{Código experimental : C90.170 (CIP 390478.9). \\ Pedigree

\author{
: Serrana XXY.4.
}

La variedad argentina serrana, utilizada como progenitor femenino, se caracteriza por su alto rendimiento y resistencia al virus del enrollamiento de la hoja (PLVR). El progenitor masculino XY.4 es un clon mejorado del departamento de Genética y Mejoramiento del Centro Internacional de la Papa (CIP). Su principal atributo es su gran tolerancia a los virus PVX y PVY y su precocidad (80-90 dias).

\section{Características de la planta:}

Vigor

: Bueno.

Altura media : $50 \mathrm{~cm}$.

Nro de tallos

Hojas

Pubescencia

Flores

: 4-5 por planta.

: Verde claro, con foliolos anchos.

Bayas

Brotes

Número de tubérculos: Medio (8-10).

Periodo de latencia : Medio ( $8-10$ semanas). 
Calidad del tubérculo:

$\begin{array}{ll}\text { Materia seca } & : 20.5 \% . \\ \text { Azúcar reductor } & : \text { : } 05 \% . \\ \text { Calidad de hojuelas } & : \text { Buena. } \\ \text { Color de hojuelas } & : \text { Buena (2.7). } \\ \text { Calidad de la fritura } & : \text { Buena. }\end{array}$

\section{Resistencia a plagas y enfermedades:}

Inmune a los virus $X$ y $Y$, muy buena resistencia a PLRV, moderadamente resistente al nemátodo del nudo de la raíz, Meloydogyne incognita, y algo tolerante a la marchitez bacteriana.

\section{Resistencia a estreses abióticos:}

$\begin{array}{ll}\text { Salinidad } & \text { : Alta }(6-10 \mathrm{mmh}) . \\ \text { Sequía } & : \text { Media (riego restringido). } \\ \text { Calor } & \left.: \text { Alta (Prom } .23-25^{\circ} \mathrm{C}\right) . \\ \text { Toxicidad de boro } & : \text { Media }(5-10 \mathrm{ppm}) .\end{array}$

Periodo vegetativo:

Precoz, 90 días.

\section{Adaptación:}

Esta variedad se adapta a las condiciones de la costa central y sur, y a la zona subtropical media.

\section{Época de siembra:}

Su tolerancia al calor la hace apta para cultivos en primavera, verano y otoño. Se recomienda sembrar a principios de setiembre (primavera) y a principios de marzo (otoño).

\subsection{VARIEDAD PRIMAVERA} $\begin{array}{ll}\text { Código experimental } & : \text { SDC 91.906, CIP 392781.1. } \\ \text { Pedigree } & : \text { B71.74.49 x XY.13. }\end{array}$

El clon superior B71.74.49 generado por el Instituto Agronómico de Balcarce, Argentina, y usado cono progenitor femenino para generar este híbrido, es un clon de alto rendimiento y resistente al virus del enrollamiento de la papa (PLRV). El progenitor masculino XY.13 es un clon élite generado por el departamento de Genética y Mejoramiento del CIP, proviene de una familia híbrida muy precoz, tolerante al calor y con resistencia a los virus PVX y PVY. Las características de ambos progenitores fueron ensamblados para generar este clon superior, hoy variedad "primavera".

\section{Características de la planta:}

$\begin{array}{ll}\text { Vigor } & : \text { Muy alto. } \\ \text { Altura } & : \text { } 60-80 \mathrm{~cm} . \\ \text { Tallos } & : 5-6 \text { por planta. } \\ \text { Hojas } & : \begin{array}{l}\text { Verde oscuras, con foliolos } \\ \text { anchos. }\end{array} \\ \text { Pubescencia } & : \text { Mediana. } \\ \text { Flores } & : \text { Blancas, } \\ & \text { abundante. } \\ \text { Bayas } & : \text { Muy escasas o ninguna. } \\ \text { Fertilidad del polen } & : \text { Muy baja }(5-10 \%) .\end{array}$

Características del tubérculo:

$\begin{array}{ll}\text { Estolones } & : \text { Cortos, medios. } \\ \text { Tuberización } & : \text { Semicompacta. } \\ \text { Forma } & : \text { Oval-redondeada. } \\ \text { Tamaño } & : \text { Mediano a grande. } \\ \text { Color de la piel } & : \text { Crema-amarillento. } \\ \text { Color de la pulpa } & : \text { Amarillo oscuro. } \\ \text { Ojos } & : \text { Superficiales. } \\ \text { Brotes } & : \text { Morado oscuro, } \\ & \text { pubescentes. }\end{array}$

Nro. de tubérculos : Alto.

Periodo de latencia : Medio (8-10 semanas).

\section{Calidad del tubérculo:}

$\begin{array}{ll}\text { Materia seca } & : 20 \% . \\ \text { Azúcares reductores } & : 0.05 \% . \\ \text { Calidad de hojuelas } & : \text { Muy buena. } \\ \text { Color de hojuelas } & : \text { Muy bueno. } \\ \text { Calidad de fritura } & : \text { Muy bueno. } \\ \text { Color de fritura } & : \text { Muy bueno. } \\ \text { Calidad culinaria } & : \text { Buena. }\end{array}$

\section{Resistencia a plagas y enfermedades}

\section{Resistencia a virus:}

Inmune a PVX

Inmune a PVY

Muy resistente a PLRV

\section{Resistencia a nemátodos}

Buena resistencia de campo al nemátodo del nudo de la raíz (RKN), Meloidogyne incognita, M.javanica y M.arenaria.

\section{Resistencia a hongos}

Resistencia moderada de campo a la rancha de la 
papa, Phytophthora infestans. Resistencia moderada de campo al tizón temprano, Alternaria solani.

\section{Resistencia a estreses abióticos:}

$\begin{array}{ll}\text { Salinidad } & : \text { Media (4-6 mmhs). } \\ \text { Sequía } & : \text { Media ( riego restringido). } \\ \text { Calor } & : \text { Alta }\left(23-25^{\circ} \mathrm{C}\right) . \\ \text { Toxicidad por boro } & : \text { Media }(4-7 \mathrm{ppm}) .\end{array}$

\section{Periodo vegetativo:}

Precoz ( 90-100 días).

\section{Adaptación:}

A la costa y sierra media semiárida. Tiene mejor rendimiento en primavera ( $27-30$ t/há), en invierno, otoño y verano presenta rendimientos comerciales ( 20-25 t/há). Debido a su relativa insensibilidad al fotoperiodo y a las temperaturas estacionales presenta un amplio rango de adaptación a la costa peruana.

\section{Época de siembra:}

Por su tolerancia al calor y precocidad, puede ser sembrada y cultivada en las cuatro estaciones del año, lo cual permite satisfacer la demanda continua de materia prima de la agroindustria de la papa.

\section{Producción de la semilla prebásica:}

Las plántulas in vitro o los tuberculillos libres de patógenos pueden ser solicitados al laboratorio de semilla e invernaderos del Centro Internacional de la Papa, Lima, o de la Universidad Nacional Jorge Basadre Grohmann, Tacna.

\subsection{VARIEDAD "DESÉRTICA"}

\section{Código experimental : SDC 92.045, CIP 391346.1. Pedigree \\ : C89.479 x 3875521.3.}

El progenitor femenino $\mathrm{C} 89.479$ es un clon élite generado por el departamento de Genética y Mejoramiento del CIP, proviene de una familia híbrida muy precoz, tolerante al calor y con gran resistencia a los virus PVX y PVY. El clon superior 387521.3, usado como progenitor masculino para generar este híbrido, es también un clon precoz mejorado en el CIP, tiene buen vigor y gran potencial de rendimiento. Estas carcterísticas principales de ambos progenitores fueron ensambladas para generar este híbrido superior SDC92.045, hoy variedad desértica, llamada así por su destacada adaptación a las condiciones desérticas de la costa peruana con potencial agrícola.

Características de la planta:

\begin{tabular}{|c|c|}
\hline Vigor & : Mediano a alto. \\
\hline Altura & : $50-60 \mathrm{~cm}$. \\
\hline Tallo & : $4-6$ por planta. \\
\hline Hojas & $\begin{array}{l}\text { : Verde claras, con foliolos } \\
\text { medianos. }\end{array}$ \\
\hline Pubescencia & : Escasa. \\
\hline Flores & $\begin{array}{l}\text { Blancas, } \\
\text { moderada. }\end{array}$ \\
\hline & Muy escasas o ninguna. \\
\hline idad del & Muy baja ( $5-10 \%)$. \\
\hline
\end{tabular}

\section{Características del tubérculo:}

Estolones

Forma

Tamaño

Color de la piel

Color de la pulpa

Ojos

Brotes

Nro. de tubérculos

Periodo de latencia : Corto (5-6 semanas).

\section{Calidad del tubérculo:}

$\begin{array}{lll}\text { Materia seca } & : & 21.10 . \\ \text { Azúcares reductores } & : & 0.05 . \\ \text { Calidad de las hojuelas } & : & \text { Muy buena. } \\ \text { Color de hojuelas } & : & \text { Muy bueno. } \\ \text { Calidad de fritura } & : \text { Muy buena. } \\ \text { Color de fritura } & : \text { Muy bueno. } \\ \text { Calidad culinaria } & : \text { Buena. }\end{array}$

\section{Resistencia a plagas y enfermedades:}

\section{Resistencia a virus :}

Inmune a PVX

Inmune a PVY

Resistente a PLRV

\section{Resistencia a nemátodos}

Buena resistencia de campo al nemátodo del nudo de la raíz (RKN), Meloidogyne incognita, M.javanica y M.arenaria.

\section{Resistencia a hongos}

Resistencia moderada de campo al tizón temprano, Alternaria solani. 
Resistencia a estreses abióticos:

$\begin{array}{ll}\text { Salinidad } & : \text { Mediana-alta }(4-7 \mathrm{mmhs}) . \\ \text { Sequía } & : \begin{array}{l}\text { Mediana alta (riego } \\ \text { restringido). }\end{array} \\ \text { Calor } & \left.: \text { Alta (Promedio } 24-27^{\circ} \mathrm{C}\right) . \\ \text { Toxicidad por boro } & : \text { Media }(4-7 \mathrm{ppm}) .\end{array}$

\section{Periodo vegetativo:}

Muy precoz (80-90 días).

\section{Adaptación:}

Presenta buena adaptación a las condiciones áridas y salinas con potencial agrícola de la costa. Tiene alta tolerancia al calor y relativa insensibilidad al fotoperiodo y a las temperaturas estacionales. Se adapta al cultivo en la sierra media semiárida, especialmente para la producción de semilla básica y certificada.

\section{Época de siembra:}

Debido a su gran precocidad y resiștencia a los estreses abióticos comunes de la costa, puede ser sembrada en cualquier época del año, sobre todo en la costa central y sur.

Produce óptimos rendimientos (20-25 t/há) durante la primavera y el otoño. Se recomienda sembrarla a principios de setiembre y de abril en la costa. En la sierra media en octubre y enero se pueden obtener dos cosechas de semilla básica y certificada por año para su comercialización en la costa.

\section{Producción de semilla prebásica:}

Este clon ya ha sido introducido al sistema de cultivo in vitro para limpiarlo de virus. El proceso de generación de plántulas y tuberculillos libres de patógenos está actualmente en marcha.

\subsection{VARIEDAD "BASADRE"}

\section{Código experimental : SDC 89.612. \\ Pedigree

$$
\text { : MEX.32 x XY.9. }
$$

El clon superior MEX.32 generado por el Programa Nacional de Papa de México y utilizado como progenitor femenino para generar este híbrido es de alto rendimiento y amplia resistencia de campo a la rancha de la papa Phytophthora infestans. El progenitor masculino XY.9 es un clon élite mejorado en el departamento de Genética y Mejoramiento del Centro Internacional de la Papa, proviene de una familia híbrida muy precoz, tolerante al calor y muy resistente a los virus PVX y PVY. Estas carcaterísticas principales de ambos progenitores fueron ensambladas para generar el híbrido superior SDC 89.612, hoy denominado variedad "basadre" en homenaje al 25 aniversario de la creación de Universidad Nacional Jorge Basadre Grohmann de Tacna.

\section{Características de la planta:}

$\begin{array}{ll}\text { Vigor } & : \text { Alto. } \\ \text { Altura } & : 50-60 \mathrm{~cm} . \\ \text { Tallo } & :-6 \text { por planta. } \\ \text { Hojas } & : \text { Verde claras, con foliolos } \\ & \text { muy anchos. } \\ \text { Pubescencia } & : \text { Abundante. } \\ \text { Flores } & : \text { Blancas, floración escasa. } \\ \text { Bayas } & : \text { Muy escasas o ninguna. } \\ \text { Fertilidad del polen } & : \text { Alta }(80-90 \%) .\end{array}$

\section{Características del tubérculo:}

Estolones

Forma

Tamaño

Color de la piel
Color de la pulpa
Ojos
Brotes

Nro. de tubérculos

Periodo de latencia

\section{Calidad del tubérculo:}

Materia seca

Azúcar reductor : 21.26 .

Calidad de hojuelas :

Color de hojuelas

Calidad de fritura

Color de fritura

Calidad culinaria
Muy cortos, tuberización compacta.

: Oval-elíptica.

: Mediano a grande, a los 70 días tiene el tamaño comercial.

: Crema-amarillento.

: Amarillo pálido.

: Superficiales.

: Rojo oscuro, con abundante pubescencia.

\section{Medio.}

Corto.

\section{Resistencia a plagas y enfermedades:}

\section{Resistencia a virus:}

PVX inmune.

PVY inmune.

PLRV moderada resistencia.

\section{Resistencia a nemátodos:}

Buena resistencia de campo al nemátodo del nudo de la raíz: Meloydogine incognita, M.javanica y M.arenaria. 


\section{Resistencia a hongos:}

Resistencia moderada de campo a la rancha de la papa Phytophthora infestans.

Resistencia moderada de campo al tizón temprano Alternaria solani.

\section{Resistencia a estreses abióticos:}

Salinidad

Sequía

Calor

Toxicidad de boro: Media (4-7 ppm).

\section{Periodo vegetativo:}

Muy precoz (80-90 días).

\section{Adaptación:}

Costa peruana y sierra media semiárida. Debido a su relativa insensibilidad al FOTOTEMPERAPERIODO se adapta para su cultivo con buenos rendimientos durante las cuatro estaciones del año. Sin embargo, su máximo potencial de rendimiento se obtiene durante la primavera (25-30 tn/há) y en las cuatro estaciones los rendimientos fluctúan de 20-25 tn/há en un periodo de 80 a 90 días.

\section{Época de siembra:}

Su tolerancia al calor y gran precocidad permite la siembra de esta variedad en cualquier época del año. Sin embargo, para un óptimo rendimiento se recomienda sembrar a principios de setiembre y a principios de abril en la costa central y surperuana. En la sierra semiárida se recomienda sembrar, para la producción de semilla certificada, a principios de octubre y enero.

\section{Producción de semilla prebásica:}

Este clon fue introducido al sistema de cultivo in vitro para su limpieza de virus y producción de semilla de calidad libre de patógenos. Plántulas in vitro y tuberculillos libres de patógenos se encuentran disponibles en los laboratorios de cultivo in vitro e invernaderos del Centro Internacional de la Papa y de la Universidad Jorge Basadre Grohmann de Tacna. Las organizaciones agrícolas dedicadas a la producción de semilla básica y certificada, pueden solicitar este material de propagación a costo reducido a estas instituciones.

\section{PROSPECCIÓN FUTURA DE LA ZONA AGROECOLÓGICA ÁRIDA}

El estrés de sal probablemente cause más daño a las plantas, en términos de pérdidas económicas, que otro factor de estrés abiótico. Además, sus efectos son difíciles de detectar y su daño fisiológico es elusivo. Una razón fundamental para ejecutar trabajos de mejoramiento genético de plantas para estrés ambiental, es que mucho de la expansión de los cultivos del Tercer Mundo en el futuro, será en suelos marginales, no adecuados para una agricultura comercial intensa.

Modificando o controlando el medio ambiente es otra alternativa para controlar la salinidad. La interrelación genética-medio ambiente puede ser optimizada a través de estudios de mejoramineto genético de la planta con prácticas culturales, tal como se puede mostrar en estos experimentos con clones tolerantes a salinidad bajo riego por exudación. En el sistema de riego tecnificado, ya sea por goteo o exudación, hay un ahorro extraordinario de agua, además, mantiene el cultivo bajo estrés moderado por el suministro permanente y suficiente de humedad. Por consiguiente, un manejo integrado de los suelos árido-salinos de potencial agrícola, engloba la utilización de un riego tecnificado que proporcione un gran ahorro de agua, y la incorporación de variedades mejoradas tolerantes a salinidad y sequía. Se calcula que en la próxima década, los agricultores expandirán su frontera agrícola hacia suelos marginales, cuando estas áreas sean el último recurso para la producción de alimentos en el Tercer Mundo, con una explosión demográfica creciente. Nosotros pensamos que la explotación del potencial de papa y camote, desarrollando nuevas variedades adaptadas a estos suelos marginales, irá paralela a la ampliación de la frontera agrícola en el desierto de la costa peruana.

La creciente demanda mundial de alimentos significa que más cultivos deben realizarse en zonas marginales, lo cual conlleva a problemas de estrés abiótico.Los suelos marginales presentan serios problemas de salinidad, acidez, alcalinidad, deficiencia de minerales y toxicidad de elementos como el boro, aluminio y hierro.y Mejorar las plantas para la tolerancia a estreses abióticos y con buenos caracteres agronómicos, son dos caminos para incrementar la producción agrícola (Upadhya et al 1990). En este sentido, el caudal genético de la papa ofrece una valiosa heredabilidad variable para el mejoramiento de resistencia al estrés. Esta variabilidad ha empezado a ser explotada en las zonas árido-salinas del desierto surperuano. Desde el inicio de este proyecto de investigación colaborativa a principios de 1985 , hasta hoy día, siempre hemos tenido en mente aplicar el principio universal técnico y moderno de que: "El principal objetivo de la investigación fitogenética es obtener beneficios económicos de la superioridad heredada o de una combinación favorable de genes". 


\section{NUEVAS HIPÓTESIS PLANTEADAS}

Durante los doce años de investigación en mejoramiento y adaptación de papa se han generado cerca de 600 clones promisorios, resistentes a estreses abióticos y con buenas características agronómicas. Observaciones realizadas en experimentos de campo y ocasionalmente en invernaderos, conducen a plantear algunas hipótesis en el mejoramiento de papa en zonas árido-salinas, para su análisis futuro. Estas hipótesis se resumen en lo siguiente:

1. Existe una correlación entre la resistencia a salinidad y la resistencia a sequía. Los clones avanzados, resistentes a salinidad, muestran también una marcada resistencia a sequía moderada o riego restringido.

2. No existe correlación entre la resistencia a salinidad con la resistencia al nemátodo del nudo de la raíz, M.incógnita (RKN). Muchos clones promisorios y avanzados con resistencia a los estreses abióticos (salinidad, boro y sequía) han sido descartados por su susceptibilidad al ataque de RKN.

3. Hay una tendencia de los clones precoces tolerantes a estreses abióticos de presentar un vigor del follaje moderado y un mayor índice de cosecha en las zonas áridas y salinas.

4. Hay una correlación baja entre la resistencia a estreses abióticos a nivel de plántula (genotipo o seedlings) y la resistencia a nivel de generaciones clonales.

5 Existe variabilidad genética para la insensibilidad al fotoperiodo correlacionado con una producción comercial sostenida en el germoplasma mejorado de papa para zonas áridas. Se puede seleccionar clones o familias TPS para una producción comercial en las cuatro estaciones del año.

6. Hay una correlación positiva muy baja entre el grado de vigor del follaje y el peso total del tubérculo, bajo condiciones de suelos áridos y salinos.

7. No hay correlación entre el grado de clorosis, quemaduras de bordes de hojas por efecto de la toxicidad del boro edáfico y la capacidad de producción de tubérculos.
8. No hay correlación entre la resistencia a salinidad y la resistencia a toxicidad de boro.Parece que ambas resistencias están controladas por la acción de diferentes grupos de genes.

9. Los estreses abióticos en zonas árido-salinas afectan la calidad culinaria en los tubérculos de papa, sobre todo la acumulación de glicoalcaloides (solanina). Es necesario seleccionar clones "resistentes" a esta acumulación, la cual se ha detectado con mayor frecuencia en clones con tubérculos de pulpa amarilla.

10. El estrés moderado de sequía en un estado avanzado del crecimiento de la planta de papa de clones precoces y tolerantes a estreses abióticos, favorece la calidad de los tubérculos destinados para procesamiento industrial (tanto en forma, tamaño, materia seca y calidad de fritura).

11. Hay diferentes respuestas fenotípicas al efecto del fotoperiodo en los clones mejorados de papa y en familias híbridas de semilla botánica , especialmente en latitud $18^{\circ} \mathrm{Sur}$, bajo condiciones de Tacna.

12. Parece existir una correlación entre el tipo de pigmentación de la piel de papa, con la reacción al ataque de RKN. La mayoría de los clones de papa de piel roja o rosada, muestran susceptibilidad de campo a RKN.

13. No hay correlación entre la tolerancia al calor y la tolerancia a bajas temperaturas en el germoplasma mejorado de papa para zonas áridosalinas. Sin embargo, existe una baja frecuencia de clones élites con ambos atributos de adaptación.

\section{GENERACIÓN DE SEMILLA DE CALIDAD LIBRE DE VIRUS PARA DISTRIBUCIÓN NACIONAL}

En vista de la creciente demanda de semilla de las variedades mejoradas de papa y camote desérticas, por parte de los agricultores y semilleristas de la costa surperuana, se inició un programa para la generación de semilla de calidad libre de virus y otros patógenos a partir del cultivo in vitro de tejidos de papa. Diez clones élites de papa fueron introducidos al sistema de cultivo in vitro, por el tratamiento de termoterapia, cultivo de meristemos, micropropagación y pruebas serológicas de ELISA, para determinar el buen estado sanitario de 
los propágulos. Este procedimiento inicial se realizó en los laboratorios de biotecnología del Centro Internacional de la Papa.

Los clones fueron limpiados de virus, dando resultados negativos en pruebas ELISA para los virus PVX, PVY, PLRV, APMV, PVS y APLV. Luego se entregó al presente proyecto dos tubos que contenían una plántula in vitro de cada variedad.Este material fue masalmente micropropagado en el laboratorio de biotecnología - sección papa de la Universidad Nacional de Tacna. Las variedades inicialmente micropropagadas fueron Tacna, Costanera, Basadre, primavera y Desértica para generar semilla prebásica de primera generación clonal. Las plántulas fueron multiplicadas en condiciones de invernadero y transplantadas a camas substratos de arena y musgo para la producción de tuberculillos (minitubers) y posterior multiplicación en el campo para la distribución de semilla (Fig. ${ }^{\circ} 4$ ). Actualmente, se ha obtenido un total de 3500 plántulas in vitro de estas variedades. EI proceso continuará hasta lograr por lo menos unos 80 kilos de semilla prebásica I de calidad, de cada variedad, para distribuir a los semilleristas del Cusco, Tacna, Moquegua y Arequipa. El control de calidad de la semilla prebásica, generada en los laboratorios se hará sistemáticamente, usando las pruebas serológicas de ELISA para la detección de por lo menos los seis virus más comunes que atacan el cultivo de la papa en la costa peruana.
Últimamente se ha establecido el comité de productores de papas industriales de la irrigación Majes, Arequipa (COPPIMA), para la producción comercial, mayormente de las variedades de calidad industrial: Tacna, Costanera, Basadre, Primavera y Desértica. El potencial agrícola de la irrigación Majes es cerca de 20,000 hectáreas y un clima adecuado para la producción sostenida de materia prima para la agroindustria durante todo el año. Este comité asi como otros, requerirán cientos de toneladas de semilla certificada, que posiblemente será generado en la sierra del Cusco (INIA, ARARIWA) y Andahuaylas (AGRIGAN). La Universidad Nacional de Tacna y tal vez otra institución que compita, producirá en forma sostenida los tuberculillos libres de virus y otros patógenos a los grandes semilleristas de semilla básica y certificada de la sierra sur. La agroindustria ha mostrado mucho interés en comprar la produccíon de papas de calidad industrial en Majes. De esta manera, se establecerá el ciclo de producción de plántulas in vitro hasta el procesamiento industrial. Para entrar en forma sostenida a este ciclo es necesario que la Universidad Nacional de Tacna invierta fondos en la construcción de nuevos invernaderos y en el equipamiento moderno del laboratorio de cultivo in vitro de papa.

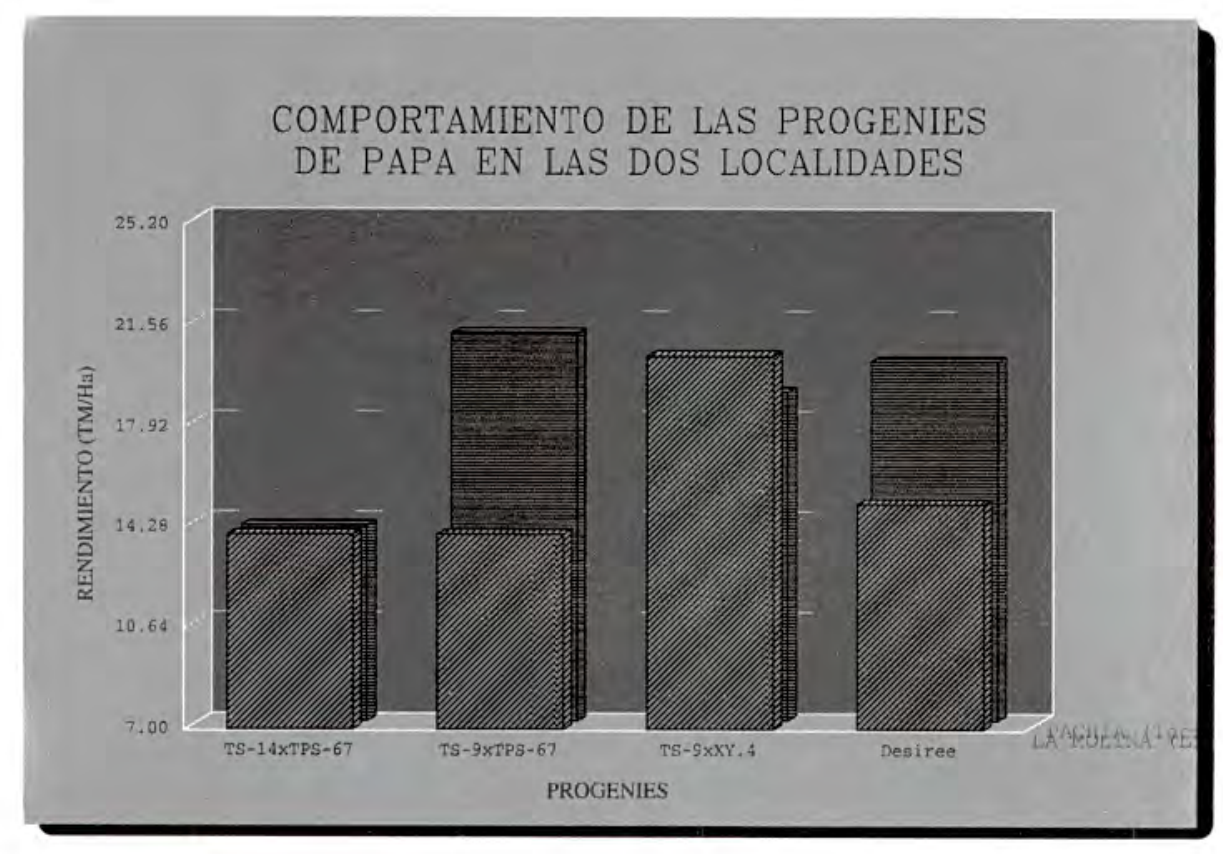



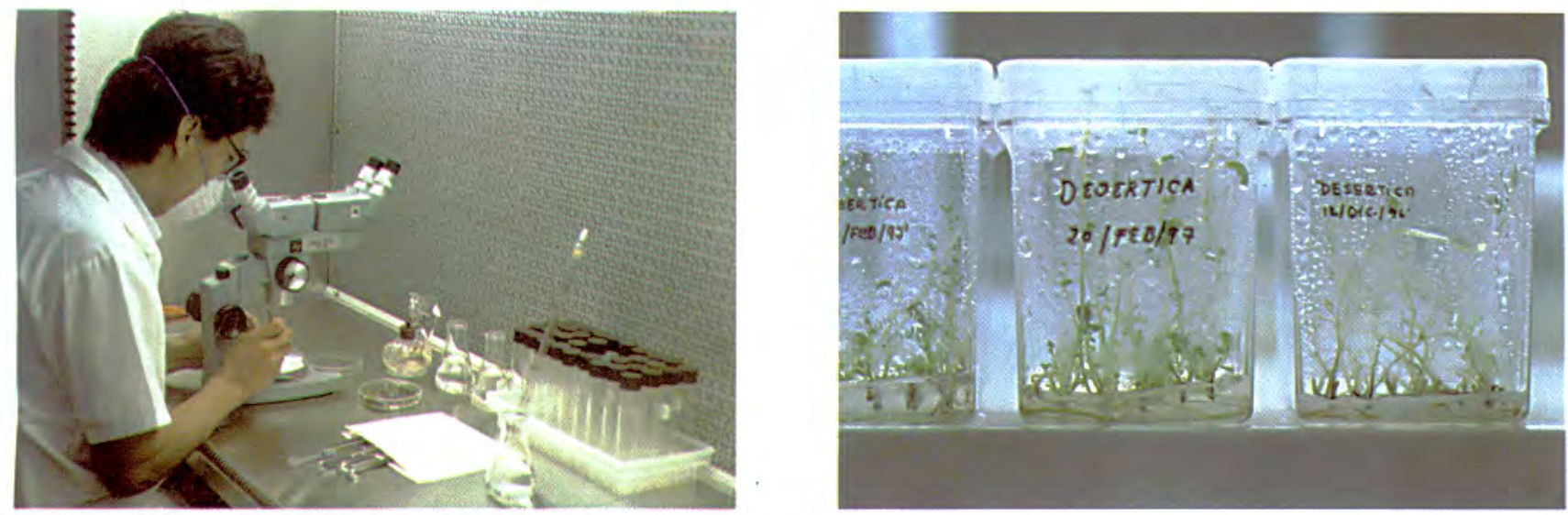

Introducción al sistema de cultivo in vitro de tejidos de papa: a) cámara de flujo laminar asceptica con instrumental esterilizado, donde se realiza la extracción de meristemos apicales con la ayuda de un potente microscopio estereoscopico y la consiguiente inoculación al medio de cultivo in vitro. b) plántulas in vitro regeneradas de la variedad desértica a partir de meristemos apicales libres de hongos, bacterias y virus.

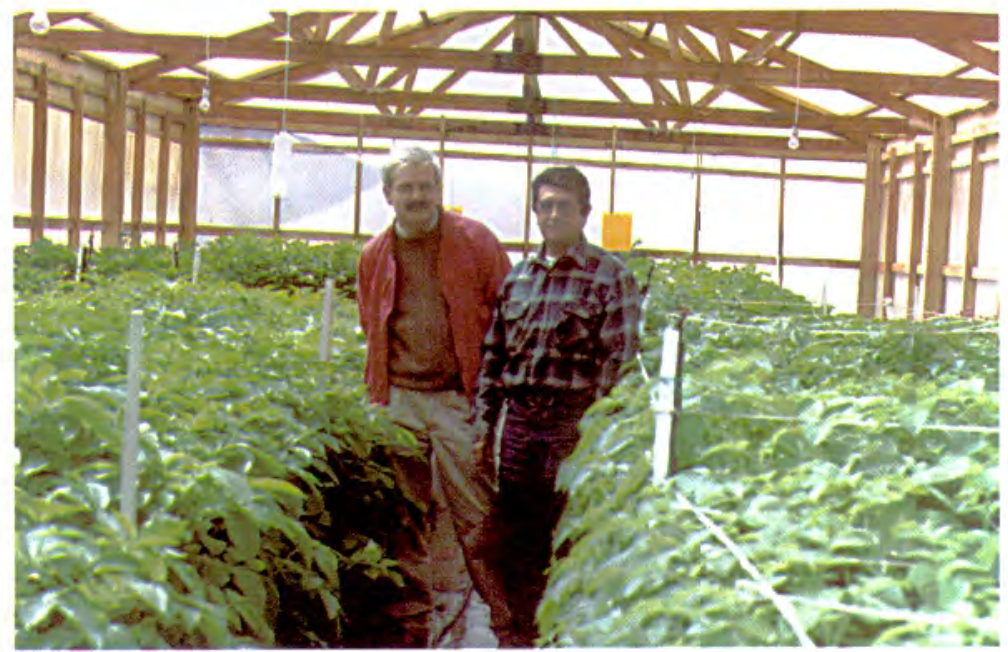

Multiplicación rápida y masal de las variedades basadre y costanera a partir de tuberculillos libres de virus producidos en Tacna. Los invernaderos conducidos bajo alta tecnología en la EEA Andenes, INIA, Cusco, garantizan la producción de semilla básica de excelente calidad. El Ing. Arie Wijntje, experto agrícola de la CEE, Majes y el Dr. Rene Chávez, coordinador del proyecto UNTAC-CIP, constatan la calidad y pureza genética de las variedades en multiplicación.

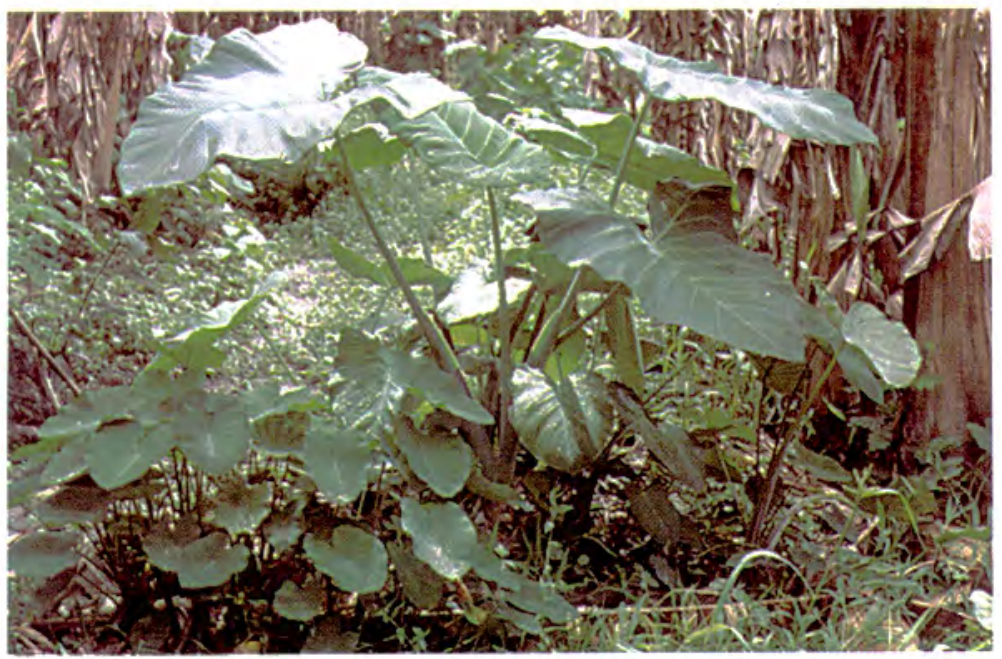

Tuberíferas del trópico bajo con resistencia genética a suelos húmedos ácidos y niveles tóxicos de hierro y aluminio. La planta grande, a la deracha es una variedad nativa del Perú de la especie Xanthosoma sagitifolium $(2 n=2 x=26)$. La planta pequeña a la izquierda es una variedad mejorada de Asia tropical y pertenece a la especie Colocasia esculenta $(2 n=3 x=42)$. Ambas especies se cultivan generalmente mezcladas a veces en un mismo surco. 


\section{REFERENCIAS BIBLIOGRÁFICAS}

Buso, J.A. (1990) Os programas de melhoramento genético de batata no Brasil. Proc.INTA-PROCIPA, pp 31-34.

Chavez, R.; Upadhya, M.; Cabello R. Berríos, R.;Siles P. (1996). Producción de papa en zonas áridas y salinas a partir de semilla botánica. Factibilidad y Perspectivas.Rev.Ciencia y Desarrollo Nro. III, 1996.

Chavez, R,;Mendoza H.;Espinoza, J. (1995) Breeding sweet potato for adaptation to arid and saline soils.CIP, circular 1995, pp.2-6.

Chavez, R.(1995) Clones superiores de papa y camote adaptados a suelos árido-salinos. Revista Ciencia y Desarrollo Nro. II, 1995.

Chavez, R.; H.Mendoza; J.Espinoza; J.Florez; J.Chavez; P.Siles; M.Huacollo (1994).Ampliando la base genética para resistencia a salinidad y sequía en el germoplasma mejorado de papa y camote. Rev.Nueva Imagen $N^{\circ}$ IV,pp13-27-A.

Chávez, R.; Upadhya, M.; Mendoza, H.; Espinoza, J.; Cabello, R.; Siles, P.; Bollo, G.; Meléndez, T.; Eyzaguirre, J.; Maquera C.; Monasterio, K.; (1996). Nuevas hipótesis y avances de selección en el mejoramiento genético de papa y camote para adaptación a suelos áridos y salinos. Rev.Ciencia y Tecnología. Vol I, No. 4.

Ekanayake, I.J. (1994) Estudios sobre el estrés por sequía y necesidades de riego de la papa. Guia de investigación, CIP 30 .

Espinoza, J.; Chávez R.; y Mendoza, H. (1986) Factibilidad de mejoramiento genético de papa en suelos salinos. Primer Congreso Peruano de Genética, Lima. Abstracts.

Jatala, $P .(1978)$. Studies of the interretionships of the plant parasitic nematodes and other organismos on potatoes 2nd Nematode P.C. International Potato Center. Lima-Perú, pp 191-193.

Guerra, C. y Zegarra R.(1995). Áfidos y hospederos naturales del valle de Tacna.Revista Ciencia y Tecnologia Vol. II 1995.
Mendoza, H.;Chavez, R.; Espinoza, J.; Arévalo N. Diaz (1991) L. Avances en el mejoramiento de papa para zonas árido-salinas. Congreso Latinoamenricano de la Papa.Lima, Perú.1991.

Ponnamperuna. F.N. (1982) Mejoramiento de plantas cultivadas para tolerancia al estrés adáfico. En Plant improvement and. somatic cell genetics. Edit. Indra Vasil. et al 1982.

Rick,C.(1982) El potencial del germoplasma exótico de tomate para el mejoramiento genético. En plant improvement and Somatic gell genetics. Edit. Indra Vasil et al, 1982.

Roca, W.M.; Arias D.I.; Chávez, R. (1990). Métodos de conservación in vitro del germoplasma. En Cultivo de tejidos en la agricultura. Edit. Bogotá, Colombia.

Sindem, S.L. y R.E. Webb, 1974.Effect of enviroment on glycoalkaloid content of six potato varieties al 39 locations.Technical Bolletin Nro.1472.USDA.

Salazar,L.F.(1996). Los virus de la papa y su control. Edit CIP, $226 \mathrm{pp}$.

Thompson, P.G., Mendoza H.A. y Plaisted.L. (1983). Estimación de parámetros genéticos relacionados a la propagación de la papa por semilla botánica en una población indígena. American Potato Journal, p p 393-401.

Thompson, P.G. y Mendoza H.A. (1984). Estimados de variancia genética en una población heterogénea de papa, propagada por semilla botánica.American Potato Journal.

Upadhya, M. D. y Thakur K.C. (1990). Constraints and strategies for true potato seed (TPS) production. Group meeting on commercial adoption of TPS technology- Problems and prospecvts. New Delhi, Aug. 17-18, 1990.

Upadhya, M.D.; Kadian, M.S., Thakur, K.C., Khatana, V.S. (1990). Potential of true potato seed (TPS) f o r p o t a to produc-tion in different agroclimatic zones of India.EARP abstracts. 11th Triennal Conference of the European Association for Potato Research, Edinburgh, Scotland, Jul 8- 13,1990, pp 532-533. 
TABLA №1 FAMILIAS HÍBRIDAS TPS PROMISORIAS, SELECCIONADAS POR SU PERFORMANCIA AGRONÓMICA EN LA SERRANÍA DE TACNA , A 3000 m.s.n.m., BAJO CONDICIONES DE FOTOPERIODO LARGO $Y$ BAJA TEMPERATURA .

PERIODO DE CRECIMIENTO : 90 DÍAS

NÚMERO TOTAL DE FAMILIAS TPS EXPERIMENTADAS : 51

DISEÑO : BCR CON TRES REPETICIONES

INCIDENTE DE ENFERMEDAD : ALTERNARIA SOLANI (EB)

\begin{tabular}{|c|l|c|c|c|c|}
\hline $\begin{array}{c}\text { NÚMERO } \\
\text { DE ORDEN }\end{array}$ & \multicolumn{1}{|c|}{ FAMILIA TPS } & $\begin{array}{c}\text { RENDIMIENTO } \\
\mathrm{g} / \mathrm{PI} .\end{array}$ & $\begin{array}{c}\text { GAP } \\
\mathrm{X}\end{array}$ & $\begin{array}{c}\mathrm{N}^{\circ} \mathrm{PI} . \\
\text { CON EB }\end{array}$ & $\begin{array}{c}\mathrm{N}^{\circ} \mathrm{DE} \\
\text { GEN. SELEC. }\end{array}$ \\
\hline 1 & LT.8xR.128.6 & 510 & 7 & 3 & 5 \\
2 & TS.6x104.12.LB & 450 & 7 & 1 & 4 \\
3 & CFK69.1x104.12.LB & 410 & 5 & 0 & 2 \\
4 & TS.14x104.12.LB & 342 & 5 & 2 & 0 \\
5 & TS.11x104.12.LB & 340 & 7 & 2 & 3 \\
6 & ATZIMBAx104.12.LB & 370 & 5 & 5 & 2 \\
7 & TS.6x104.12.LB & 330 & 5 & 4 & 2 \\
8 & MFIIx104.12.LB & 330 & 5 & 7 & 1 \\
9 & SERRANAx104.12.LB & 310 & 5 & 6 & 1 \\
10 & TS.10x104.12.LB & 310 & 5 & 5 & 0 \\
11 & SERRANAxTPS.67 & 305 & 5 & 2 & 3 \\
12 & TS.9x104.12.LB & 308 & 5 & 2 & - \\
13 & DESIREE & 300 & 5 & 4 & \\
\end{tabular}

^ GAP : Performancia agronómica general (Escala : 1,3,5,7,9). 
TABLA № 2 EVALUACIÓN DE FAMILIAS TPS BAJO SUELOS ÁRIDOS Y SALINOS CON BAJOS NIVELES DE SALINIDAD Y BORO

LOCALIDAD : LAS VILCAS, TACNA, 500 m.s.n.m.

PERIODO DE CRECIMIENTO : 90 DÍAS DESPUÉS DEL TRANSPLANTE, (PRIMAVER

BAJO CONDICIONES DE BAJA A ALTA TEMPERATURA,

Y DÍAS CORTOS A DÍAS LARGOS

DISEÑO : CRB, 3 REPETICIONES

\begin{tabular}{|c|c|c|c|c|c|}
\hline $\begin{array}{l}\text { NÚMERO } \\
\text { DE ORDEN }\end{array}$ & FAMILIA TPS & $\begin{array}{c}\text { \% DE } \\
\text { SUPERVIVENCIA } \\
\text { A LOS } 30 \text { DÍAS } \\
x \\
\end{array}$ & $\begin{array}{c}\text { VIGOR } \\
\text { DE FOLLAJE } \\
\text { A LOS } 80 \mathrm{D} . \\
\mathrm{X}\end{array}$ & $\begin{array}{c}\text { RENDIMIEN. } \\
\text { g/pl } \\
\mathrm{X}\end{array}$ & $\begin{array}{c}\mathrm{N}^{\circ} \mathrm{DE} \\
\text { GENOTIPO } \\
\mathrm{S} \\
\text { SELECC. } \\
{ }^{*}\end{array}$ \\
\hline 1 & MF-I X TPS-67 & 73,3 & 7,0 & 750,0 & 3 \\
\hline 2 & DESIREE (CONTROL) & 89,0 & 5,0 & 650,0 & - \\
\hline 3 & I-1035 X TPS.113 & 63,0 & 7,0 & 570,0 & 5 \\
\hline 4 & TS. 6 X TPS. 13 & 70,0 & 6,3 & 530,0 & 4 \\
\hline 5 & MF-I X TPS. 13 & 50,6 & 5,6 & 460,0 & 1 \\
\hline 6 & LT. $8 \times$ TPS. 67 & 80,0 & 5,7 & 410,0 & 4 \\
\hline 7 & CEW.69.1 X TPS. 67 & 72,0 & 7,0 & 400,0 & 4 \\
\hline 8 & TS- $13 \times$ TPS .67 & 69,2 & 6,3 & 300,0 & 3 \\
\hline 9 & ATZIMBA $\times$ TPS. 13 & 68,2 & 6,3 & 290,0 & 2 \\
\hline 10 & TPS. 25 X TPS. 13 & 75,3 & 5,0 & 270,0 & 1 \\
\hline 11 & TS. 14 X TPS. 13 & 38,8 & 4,3 & 230,0 & - \\
\hline
\end{tabular}

* Un total de 27 clones promisorios fueron seleccionados. 
TABLA № 3 FAMILIAS HÍBRIDAS SELECCIONADAS BAJO CONDICIONES DE VERANO CÁLIDO Y DÍAS LARGOS EN TACNA

SELECCIÓN BASADA EN MÁS DEL $50 \%$ DE SUPERVIVENCIA DE PLÁNTULAS Y MÁS DEL 70\% DE HABILIDAD DE TUBERIZACIÓN DE LAS PLÁNTULAS POR FAMILIA

NÚMERO TOTAL FAMILIAS TPS EXPERIMENTADAS : 42

NÚMERO TOTAL DE PLÁNTULAS POR FAMILIA : 60 REP : 3

TIPO DE SUELO : ARENOSO-LIMOSO, CON NIVELES MEDIOS DE SALINIDAD Y TOXICIDAD DE BORO.

INCIDENTE DE ATAQUE DE INSECTOS : RUSSELIANA SOLANÍCOLA

\begin{tabular}{|c|c|c|c|c|c|}
\hline $\mathrm{N}^{0}$ & FAMILIA TPS & $\begin{array}{c}\% \\
\text { SUPERV. }\end{array}$ & $\begin{array}{c}\% \\
\text { TUBERIZ. }\end{array}$ & $\begin{array}{c}\text { RENDIM. } \\
\mathrm{g} / \mathrm{pl}\end{array}$ & $\begin{array}{l}\mathrm{N}^{\circ} \text { DE GENOT. } \\
\text { SELECC. }\end{array}$ \\
\hline 1 & TS.9 $\times$ XY.4 & 84,0 & 89,0 & 581,0 & 14 \\
\hline 2 & TS. $9 \times$ TPS. 67 & 81,0 & 87,0 & 570,0 & 02 \\
\hline 3 & TS. $5 \times$ TPS. 13 & 71,0 & 85,0 & 531,0 & 01 \\
\hline 4 & TS. $5 \times$ TPS. 67 & 70,0 & 80,0 & 491,0 & 02 \\
\hline 5 & TS. $14 \times$ TPS. 13 & 69,0 & 77,0 & 486,0 & 02 \\
\hline 6 & TS. $14 \times$ TPS. 67 & 66,0 & 77,0 & 437,0 & 04 \\
\hline 7 & MF-II x TPS.13 & 65,0 & 75,0 & 410,0 & 03 \\
\hline 8 & MF-II x TPS.67 & 60,0 & 76,0 & 377,0 & 07 \\
\hline 9 & MF-I x TPS. 13 & 58,0 & 74,0 & 534,0 & 03 \\
\hline 10 & ATZIMBA $x$ TPS. 13 & 51,3 & 72,7 & 315,0 & 03 \\
\hline 11 & $\begin{array}{l}\text { COSTANERA } \\
\text { (CONTROL) }\end{array}$ & 95,0 & 100,0 & 313,0 & - \\
\hline
\end{tabular}

Todas las familias mencionadas arriba, serán revisadas otra vez, junto con las 23 familias TPS que parecen no adaptadas a condiciones de verano cálido en Tacna, durante el próximo otoño e invierno en Tacna. 
TABLA №4 EVALUACIÓN DE FAMILIAS TPS-TF PROMISORIAS EN SUELOS ÁRIDOS BAJO CONDICIONES DE SALINIDAD MODERADA Y BAJA TEMPERATURA $Y$ FOTOPERIODO CORTO

LOCALIDAD : PACHÍA, TACNA, 1000 m.s.n.m. ,LAT. 18 `S

PERIODO DE CRECIMIENTO : 90 DÍAS, INVIERNO

\begin{tabular}{|c|c|c|c|c|c|}
\hline $\mathrm{N}^{\circ}$ & TPS - TF & No HP & $\begin{array}{c}\text { T/ha } \\
\text { RENDIM. }\end{array}$ & $\mathrm{G} / \mathrm{P}$ & GAP * \\
\hline 1 & TS-9 XXY.13 & 34 & 32,5 & 956 & 7 \\
\hline 2 & TS-9 XXY.13 & 30 & 34,0 & 1133 & 9 \\
\hline 3 & TS-9 X XY.13 & 30 & 30,5 & 1016 & 9 \\
\hline 4 & TS-9 X XY.13 & 30 & 26,0 & 867 & 7 \\
\hline 5 & TS-9 X XY.4 & 34 & 26,4 & 776 & 9 \\
\hline 6 & TS-9 XXY.4 & 35 & 24,5 & 700 & 7 \\
\hline 7 & TS-9 X XY.4 & 31 & 19,0 & 612 & 7 \\
\hline 8 & TS-9 XXY.4. & 27 & 24,0 & 889 & 9 \\
\hline 9 & DESIREE & 24 & 19,0 & 792 & 7 \\
\hline 10 & DESIREE & 31 & 16,0 & 516 & 5 \\
\hline 11 & MF-I XXY.13 & 31 & 16,0 & 516 & 5 \\
\hline 12 & $M F-I X X Y .13$ & 31 & 18,0 & 580 & 5 \\
\hline 13 & MF-I XXY.13 & 24 & 23,0 & 958 & 9 \\
\hline 14 & DESIREE & 26 & 16,0 & 615 & 7 \\
\hline 15 & TPS-7 $\times$ XY.13 & 28 & 18,0 & 643 & 5 \\
\hline 16 & TPS-7 $\times$ XY.13 & 32 & 19,0 & 594 & 5 \\
\hline 17 & TPS-25 x XY.13 & 24 & 13,0 & 542 & 3 \\
\hline 18 & C230-LM86 x XY.13 & 30 & 17,0 & 567 & 3 \\
\hline 19 & MF-II x XY.13 & 30 & 18,0 & 600 & 5 \\
\hline 20 & SERRANA $\times$ TS.3 & 25 & 25,0 & 1000 & 9 \\
\hline 21 & TS-6 $\times$ XY.4 & 31 & 23,0 & 742 & 7 \\
\hline 22 & TS-10 x XY.13 & 28 & 18,0 & 643 & 5 \\
\hline 23 & C914-LM86B x XY.13 & 36 & 24,0 & 667 & 5 \\
\hline 24 & $1-1039 \times \mathrm{TS} .5$ & 25 & 20,0 & 800 & 9 \\
\hline 25 & TPS-2 $\times$ XY.13 & 41 & 22,0 & 536 & 7 \\
\hline 26 & SERRANA $\times \mathrm{XY} .13$ & 31 & 23,0 & 742 & 7 \\
\hline 27 & GRANOLA x XY.20 (CLONE) & 18 & 9,0 & 500 & 5 \\
\hline 28 & SERRANA $\times$ TS.7 & 35 & 25,0 & 714 & 9 \\
\hline 29 & MF-II x TS.13 & 33 & 24,0 & 727 & 5 \\
\hline
\end{tabular}

* El mejor rendimiento agronómico general(GAP)relacionado al rendimiento de tubérculos y calidad del tubérculo (uniformidad de forma, tamaño y color) así como el valor comercial, ha sido observado entre plantas de las siguientes familias TPS-TF:

TS- $9 \times$ XY.4, TS- $9 \times$ XY.13, SERRANA $\times$ TS.3, I-3039 $\times$ TS-5, SERRANA $\times$ TS.7 
TABLA № 5 EVALUACIÓN DE FAMILIAS TUBÉRCULO Y CLONES AVANZADOS, RESISTENTES A ESTRESES ABIÓTICOS, BAJO CONDICIONES DE BAJA TEMPERATURA Y DÍAS CORTOS EN SUELOS ÁRIDOS Y SALINOS

PERIODO DE CRECIMIENTO : 90 DÍAS , AL NIVEL DEL MAR, SUELOS ARENOSOS Y SALINOS IRRIGADOS CON CINTAS EXUDANTES

DISEÑO : CRB , CON 4 REPETICIONES

\begin{tabular}{|c|l|c|c|c|}
\hline ORDEN & \multicolumn{1}{|c|}{ CLON/TF-TPS } & $\begin{array}{c}\text { RENDIMIENTO } \\
\times \mathrm{g} / \mathrm{pl}\end{array}$ & $\begin{array}{c}\text { CALIDAD DEL } \\
\text { TUBÉRCULO }\end{array}$ & $\begin{array}{c}\text { COLOR DEL } \\
\text { TUBÉRCULO }\end{array}$ \\
\hline 1 & BASADRE & 649 & 9 & CS-CF \\
2 & SDC 92.023 & 595 & 9 & RS-YF \\
3 & SDC 89.315 & 587 & 9 & CS-CF \\
4 & SDC 92.085 & 566 & 7 & CS-CF \\
5 & SDC 92.121 & 534 & 7 & CS-WF \\
6 & SDC 387971.5 & 521 & 7 & CS-WF \\
7 & TACNA & 485 & 9 & CS-CF \\
8 & SDC 92.132 & 450 & 7 & CS-CF \\
9 & SDC 89.262 & 426 & 9 & CS-YF \\
10 & SDC 91.640 & 396 & 7 & CS-CF \\
11 & SDC 92.172 & 381 & 7 & RS-WT \\
12 & OC 92.085 & 340 & 9 & CS-YF \\
13 & COSTANERA & 328 & 5 & CS-CF \\
14 & SDC 387776.3 & 321 & 5 & CS-YF \\
15 & DESIREE & 320 & 5 & RS-YF \\
16 & TF-TPS-BULK * & 281 & 5 & CS-CF * \\
17 & LT.8 104.12.LB * & 265 & 5 & CS-CF * \\
18 & MF-II x XY.13 * & & & CS-CF* \\
& & & & \\
\hline
\end{tabular}

${ }^{\star}$ Familias de semilla tubérculo seleccionados de TPS. 


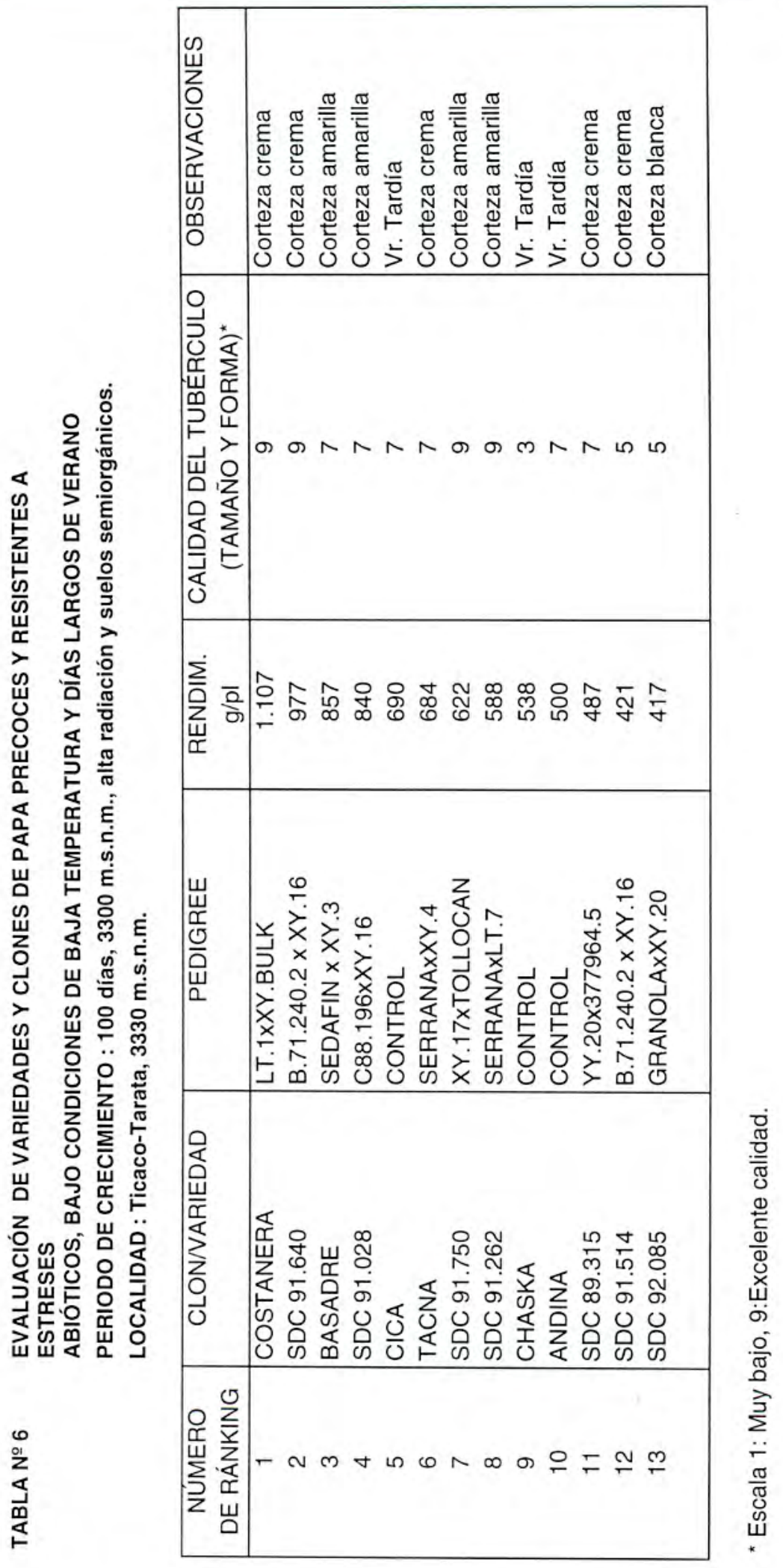


TABLA № 7 EVALUACIÓN DEL DAÑO DEL FOLLAJE CAUSADO POR EL ATAQUE DE LA MOSCA MINADORA(LIRIOMYZA SP) EN CLONES Y VARIEDADES AVANZADAS TOLERANTES A ESTRESES ABIÓTICOS BAJO SUELOS ARENOSOS Y SALINOS, EN CHACRA DE AGRICULTOR.

LOCALIDAD : LA YARADA, KM 17, TACNA, 100 m.s.n.m., SUELOS SALINOS PERIODO DE CRECIMIENTO : 90 DIAS, INVIERNO, CONDICIONES DE DÍAS CORTOS Y BAJA TEMPERATURA.

\begin{tabular}{|c|c|c|c|c|c|c|}
\hline \multirow{2}{*}{$\begin{array}{c}\text { NÚMERO } \\
\text { DE } \\
\text { RANGO }\end{array}$} & \multirow[t]{2}{*}{ CLON/VARIEDAD } & \multicolumn{4}{|c|}{$\begin{array}{l}\text { PLM } \\
\text { GRADO } \\
\text { DE } \\
\text { DAÑO * }\end{array}$} & \multirow[t]{2}{*}{ OBSERVACIONES } \\
\hline & & $\mathrm{BI}$ & BII & BIII & $x$ & \\
\hline 1 & TIKAHUASI & 3 & 3 & 1 & 2,3 & TARDÍO \\
\hline 2 & MARIA TAMBEÑA & 1 & 3 & 3 & 2,3 & MEDIO TARDÍO \\
\hline 3 & TOMASA & 3 & 3 & 3 & 3,0 & TARDÍO \\
\hline 4 & SDC 91.640 & 5 & 5 & 3 & 4,3 & PRECOZ \\
\hline 5 & PRIMAVERA & 5 & 5 & 5 & 5,0 & PRECOZ \\
\hline 6 & SDC 91.612 & 5 & 5 & 5 & 5,0 & PRECOZ \\
\hline 7 & SDC 92.140 & 5 & 5 & 5 & 5,0 & MUY PRECOZ \\
\hline 8 & SDC 92.159 & 5 & 5 & 5 & 5,0 & MUY PRECOZ \\
\hline 9 & SDC 93.156 & 5 & 7 & 5 & 5,6 & PRECOZ \\
\hline 10 & SDC 91.028 & 7 & & 5 & 6,0 & PRECOZ \\
\hline 11 & SDC 91.628 & 5 & 5 & 9 & 6,3 & PRECOZ \\
\hline 12 & SDC 92.172 & 7 & 7 & 5 & 6,3 & PRECOZ \\
\hline 13 & COSTANERA & 7 & 7 & 7 & 7,0 & MUY PRECOZ \\
\hline 14 & E 86.011 & 7 & 7 & 7 & 7,0 & PRECOZ \\
\hline 15 & E 86.692 & 7 & 7 & 7 & 7,0 & PRECOZ \\
\hline 16 & C 92.085 & 7 & 7 & 7 & 7,0 & PRECOZ \\
\hline 17 & C 93.169 & 7 & 7 & 9 & 7,6 & PRECOZ \\
\hline 18 & MARIA BONITA & 9 & 7 & 7 & 7,6 & PRECOZ \\
\hline 19 & CANCHAN INIA & 9 & 9 & 9 & 9,0 & MEDIO TARDÍO \\
\hline
\end{tabular}

* PLM daño fue evaluado a los 80 días del periodo de crecimiento con la siguiente escala:

$$
\begin{aligned}
& 1: \text { MENOS DEL 10\% DAÑADO } \\
& 3: 10-20 \\
& 5: 20-30 \\
& 7: 30-40 \\
& 9: \text { ALTAMENTE DAÑADO }(40-100 \%)
\end{aligned}
$$


TABLA NN 8 EVALUACIÓN DE DAÑO DE FOLLAJE CAUSADO POR LA CIGARRITA PLOMA (RUSSELIANA SOLANICOLA) EN CLONES Y VARIEDADES AVANZADAS DE PAPA TOLERANTES A ESTRESES ABIÓTICOS, BAJO CONDICIONES DE SUELOS NO ESTRESANTES.

LOCALIDAD : VALLE DE MOQUEGUA, ESTACION EXPERIMENTAL DE LA FUNDACIÓN PERU 1400 m.s.n.m.

PERIODO DE CRECIMIENTO : 90 DÍAS, INVIERNO, CONDICIONES DE DÍAS CORTOS

Y TEMPERATURA MEDIA.

\begin{tabular}{|c|l|c|c|c|c|l}
\hline \multirow{2}{*}{$\begin{array}{c}\text { NÚMERO } \\
\text { DE }\end{array}$} & \multicolumn{1}{|c|}{ CLON/Vr. } & \multicolumn{6}{|c|}{ GWA : DAÑO DEL FOLLAJE } & OBSERVACIONE \\
\cline { 2 - 6 } ORDEN & & BI & BII & BIII & $X$ & \\
\hline 1 & TIKAHUASI & 3 & 3 & 3 & 3,0 & TARDÍO \\
2 & MARÍA TAMBEÑA & 3 & 3 & 3 & 3,0 & MEDIO TARDÍO \\
3 & TOMASA & 3 & 3 & 3 & 3,0 & TARDÍO \\
4 & SDC 91.640 & 5 & 3 & 5 & 4,3 & PRECOZ \\
5 & SDC 91.628 & 3 & 5 & 5 & 4,3 & PRECOZ \\
6 & C 93.174 & 5 & 5 & 5 & 5,0 & PRECOZ \\
7 & C 93.159 & 3 & 9 & 5 & 5,6 & PRECOZ \\
8 & COSTANERA & 5 & 7 & 5 & 5,6 & MUY PRECOZ \\
9 & E 86.692 & 5 & 7 & 7 & 6,3 & PRECOZ \\
10 & E 86.011 & 5 & 7 & 7 & 6,3 & PRECOZ \\
11 & C 93.074 & 5 & 5 & 7 & 6,3 & PRECOZ \\
12 & SDC 92.178 & 7 & 7 & 7 & 7,0 & PRECOZ \\
13 & C 93.169 & 7 & 7 & 7 & 7,0 & PRECOZ \\
14 & SDC 91.612 (BASADRE) & 7 & 7 & 7 & 7,0 & PRECOZ \\
15 & SDC 92.140 & 7 & 7 & 9 & 7,6 & PRECOZ \\
16 & C 92.159 & 7 & 9 & 7 & 7,6 & PRECOZ \\
17 & C 93.156 & 7 & 9 & 7 & 7,6 & PRECOZ \\
18 & C 92.131 & 7 & 9 & 7 & 7,6 & PRECOZ \\
19 & CANCHAN INIA & 9 & 7 & 9 & 8,3 & MEDIO TARDÍO \\
20 & MARÍA BONITA & 7 & 9 & 9 & 8,3 & MEDIO TARDÍO \\
21 & C 92.085 & 7 & 9 & 9 & 8,3 & PRECOZ \\
& & & & & & \\
\hline
\end{tabular}



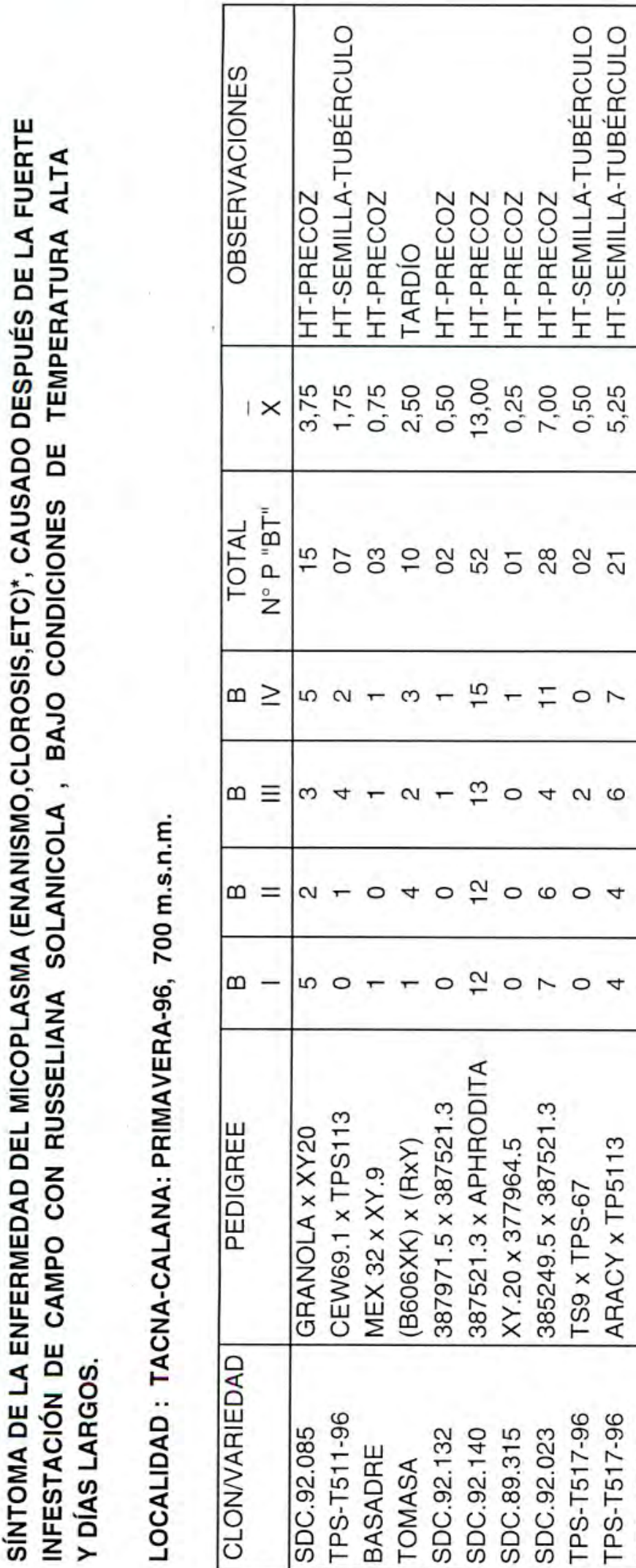

N 品

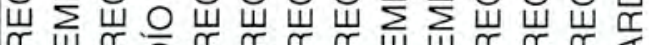

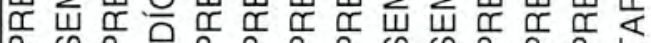
की 宔宔定它宔宔宔宔宔宔宔宔

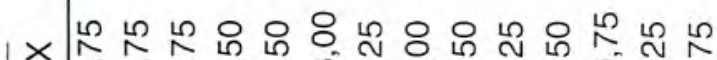
m- Ó No

\section{$\frac{1}{\omega}$}

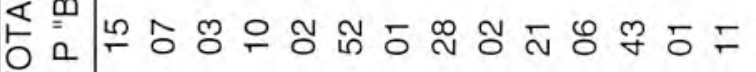
$+\stackrel{\circ}{Z}$

$\infty \geq$ $n n-m-\frac{\sigma}{n}-$ LO n n

$m \equiv m+-n-m o \forall n \in-a-n$

$m=n-0,0 \leqslant 0,0, t=0 \mathrm{n}$

$m-$ DO- O NONOANGOM

m m m

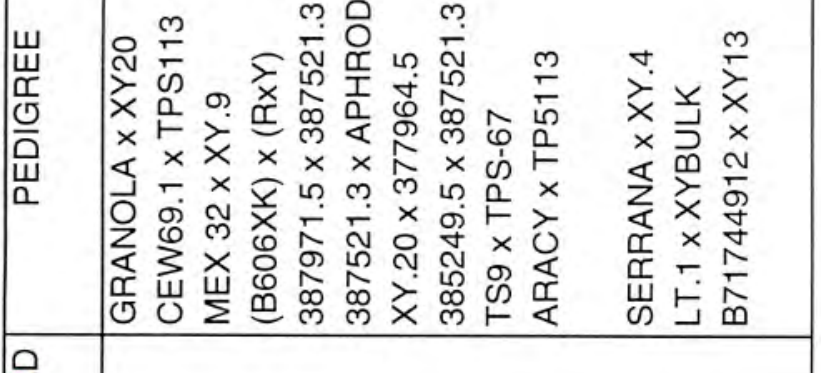

这

岸

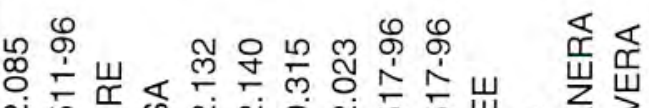
लं के

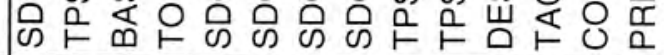

变

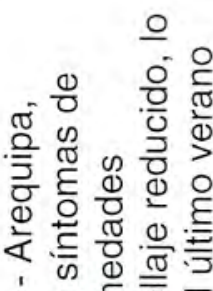

is $ᄃ$ ह 흥

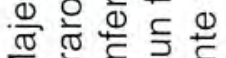

$\sum$ के $>$ 需

ब

ब)

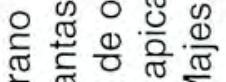
का $\frac{\pi}{0} 0$ is $\frac{\pi}{2}$ $>$ in $\frac{\pi}{2} \cdot \frac{1}{0}$

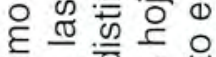
西: $\bar{\Phi}$. क त्र की के के तथ 뜨웡 Ф융으응

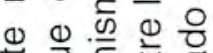
눈 ब 绕

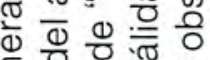
ह

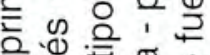
क 뜽 은 응 항 등 등 등 잉 ㅎำ

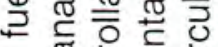

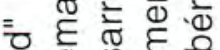
즁 is $\varepsilon$ 융

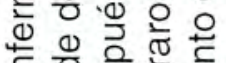

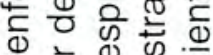
ه 흉응 है

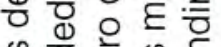

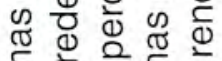
ธิ 的品㚅 क

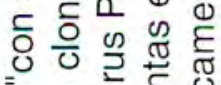

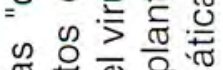

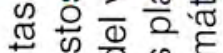
하에 응 क क 응 \& 흥으

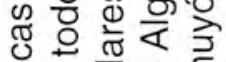
을 的的

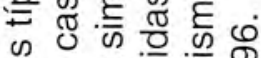

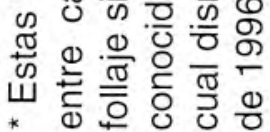


TABLA №10 CULTIVO IN VITRO, MICROPROPAGACIÓN MASAL Y PRODUCCIÓN DE MINITUBÉRCULOS DE VARIEDADES DE PAPA LIBRES DE PATÓGENOS Y RESISTENTES A ESTRESES Y CLONES MEJORADOS Y AVANZADOS.

\begin{tabular}{|c|c|c|c|c|}
\hline No & CLON / VARIEDAD & $\begin{array}{l}\text { N }{ }^{\circ} \text { IN VITRO } \\
\text { DE PLÁNTULAS }\end{array}$ & $\begin{array}{c}\mathrm{N}^{\circ} \\
\text { MINITUBÉRCULOS }\end{array}$ & $\underset{*}{\text { DISTRIBUCIÓN }}$ \\
\hline 1 & TACNA & 1240 & 3840 & EEC-PERÚ*/INIA \\
\hline 2 & COSTANERA & 1351 & 4800 & EEC-PERÚ/INIA \\
\hline 3 & BASADRE & 1025 & 3600 & EEC-PERÚ/INIA \\
\hline 4 & PRIMAVERA & 500 & 100 & EEC - INIA \\
\hline 5 & DESÉRTICA & 250 & 250 & EEC - INIA \\
\hline 6 & SDC.92.640 & 120 & - & - \\
\hline 7 & SDC.89.315 & 130 & - & - \\
\hline 8 & SDC.89.262 & 142 & - & - \\
\hline 9 & SDC.72.172 & 134 & - & - \\
\hline 10 & SDC.72.140 & 110 & - & - \\
\hline \multicolumn{5}{|c|}{ VARIEDADES DE INVIERNO (CONTROLES) } \\
\hline 11 & MARIVA & 150 & - & - \\
\hline 12 & REVOLUCIÓN & 100 & - & - \\
\hline 13 & TOMASA & 180 & - & - \\
\hline 14 & AMARILLA & 40 & - & - \\
\hline
\end{tabular}

* Actualmente, el material distribuido se encuentra en multiplicación rápida en las estaciones de semilleristas de Cusco. 